\author{
Sławomir Dorocki \\ Uniwersytet Pedagogiczny im. Komisji Edukacji Narodowej w Krakowie \\ Paweł Brzegowy \\ Uniwersytet Jagielloński, Kraków
}

\title{
Regionalne zróżnicowanie kształcenia we Francji w aspekcie rozwoju przedsiębiorczości departamentów zamorskich
}

Polityka regionalna mająca na celu niwelowanie różnic w rozwoju społeczno-gospodarczym Francji trwa już prawie pół wieku. Za jej początek przyjmuje się ustanowienie w lutym 1963 roku międzyresortowej Delegatury do spraw Zagospodarowania Przestrzennego i Działań Regionalnych (DATAR - Délégation à l'aménagement du territoire et à l'action régionale) ${ }^{1}$, której działalność na rzecz rozwoju regionów polega na koordynacji działań oraz współpracy z władzami lokalnymi i innymi podmiotami lokalnymi (Pietrzyk 1992). Jednocześnie w marcu 1964 roku dokonano pełnej dekoncentracji funkcji planistycznych na szczeblu regionalnym. Francja została podzielona na 21 regionów metropolitalnych oraz 4 departamenty zamorskie (DOM - départements d'outre-mer), w skład których wchodziły Gujana Francuska, Gwadelupa, Martynika i Réunion. Obszary te zostały uznane po II wojnie światowej za integralną część Republiki Francuskiej i włączone w politykę regionalną państwa. Delegatura do spraw Zagospodarowania Przestrzennego i Działań Regionalnych, jako organizacja państwowa, realizuje dwa główne cele. Pierwszym z nich jest zwiększenie atrakcyjności i konkurencyjności regionów. Drugim - zapewnienie spójności i niwelowanie dysproporcji rozwojowych w integrującej się Europie. To właśnie realizowana przy współpracy z Unią Europejską polityka spójności stała się współcześnie głównym instrumentem rozwoju departamentów zamorskich Francji. Działania te mogły mieć miejsce dzięki wcześniejszej decyzji Trybunału Sprawiedliwości z 1978 roku, który w odniesieniu do prawodawstwa Wspólnoty Europejskiej uznał departamenty zamorskie Francji za integralną część Republiki Francuskiej. Zaowocowało to objęciem departamentów zamorskich pierwszymi programami regionalnymi Wspólnoty w 1989 roku (program POSEIDOM).

Jednakże do dnia dzisiejszego polityka mająca na celu wyrównanie poziomu rozwoju ekonomiczno-społecznego regionów Francji nie odniosła pełnego sukcesu. Regiony pozaeuropejskie Francji od regionów metropolitalnych wciąż dzieli ogromna przepaść ekonomiczna. Niekorzystną sytuację regionów zamorskich potwierdzają demonstracje i strajki ludności, które miały miejsce w Antylach Francuskich w 2009 roku, a których źródłem były dysproporcje w rozwoju regionów zamorskich Francji w stosunku do metropolii.

\footnotetext{
${ }^{1}$ Wcześniej zadania DATAR należały do powstałego w 1960 roku Międzyministralnego Komitetu Zagospodarowania Przestrzennego (Comité Interministeriel pour l'Aménagement du Territorie - CIAT). W 2009 roku dokonano zmiany nazwy na Délégation interministérielle à l'aménagement du territoire et à l'attractivité régionale.
} 
Sytuację tę potwierdza raport senatu Francji z 2009 roku, w którym zwraca się uwagę na główne problemy departamentów zamorskich. Do czynników wpływających na opóźnienie w rozwoju gospodarczym terytoriów zamorskich zaliczone zostały między innymi ograniczenia naturalne (w tym głównie odległość od metropolii) oraz ograniczenia historyczne (np. rozwój przemysłu w obszarach DOM datuje się dopiero na drugą połowę XX wieku). Te niekorzystne uwarunkowania spowodowały uzależnienie gospodarcze DOM od Francji oraz supremację rolnictwa, turystyki i budownictwa w gospodarce regionów zamorskich (Brzegowy, Dorocki 2010). Do niekorzystnych cech wpływających na peryferyjność gospodarczą departamentów zamorskich zaliczono również wysoki poziom bezrobocia (największy w Unii Europejskiej) i ubóstwo dużej części społeczeństwa. Równie ważne są problemy społeczne związane z wielokulturowością mieszkańców terenów zamorskich. Wśród ludności nakładają się na siebie problemy językowe, etniczne, rasowe i kulturowe. Problemy te pośrednio wynikają $\mathrm{z}$ niedostosowania egalitarnego systemu kształcenia, nierespektującego zróżnicowania kulturowego regionów i powielającego wzorce z metropolii, często niezrozumiałe i obce dla ludności mieszkańców Ameryki czy Afryki.

Paradoksalnie, współcześnie głównym problemem departamentów zamorskich Francji jest uzależnienie ich rozwoju od pomocy finansowej UE. Środki finansowe przeznaczone dla najbiedniejszych regionów Unii stały się główną determinantą rozwoju gospodarczego, powodując brak inicjatyw oddolnych odpowiedzialnych za endogeniczny rozwój regionów. Szczególnie widoczne jest to w sferze działów gospodarki związanych z wysoką techniką i innowacyjnością. Dlatego, aby aktywizować wewnętrzny rozwój gospodarczy DOM, jako główne narzędzie polityki regionalnej mające na celu poprawę sytuacji terytoriów zamorskich przyjęto inwestycje $\mathrm{w}$ infrastrukturę oraz pobudzenie rozwoju przedsiębiorstw, poprzez transfer wiedzy i inwestycje w kapitał ludzki. Działania te wpisują się w ideę gospodarki opartej na wiedzy realizowaną między innymi poprzez strategię lizbońską (Dorocki 2008). Współcześnie przyjmuje się, że to właśnie kapitał ludzki jest kluczowym czynnikiem zwiększającym poziom konkurencyjności regionów, a rozwój systemu kształcenia ma istotne znacznie w przyspieszaniu tego procesu (Grodzicki 2000; Goldberg 2004; Kuźnicki 2004; Runiewicz-Wardyn 2008; Stachowiak 2008; Zioło 2008; Borowiec, Dorocki, Jenner 2009; Łukasiewicz 2009). Proces kształtowania gospodarki opartej na wiedzy dokonuje się głównie przez zwiększenie zasobów i podnoszenie jakości kapitału ludzkiego, które następuje w wyniku kształcenia na poziomie wyższym (m.in. Chojnicki, Czyż 2003, 2006, 2007, 2008; Borowiec 2008a, Sowiński 2008; Komorowski 2008). W konsekwencji inwestycje w kapitał ludzki pozwalają na stopniowe zmniejszanie się różnic w poziomie rozwoju regionalnego (Borowiec 2011; Świtała 2007). Dlatego w modelu relacji przedsiębiorczości i aktywizacji gospodarczej (Zioło 2007) ważnym uwarunkowaniem endogenicznym regionu są zasoby intelektualne, kształtowane z kolei przez zewnętrzne czynniki, na przykład system edukacji.

W związku z powyższymi przesłankami oraz zwracając uwagę na rolę kapitału ludzkiego w rozwoju regionalnym, celem artykułu jest analiza regionalnego zróżnicowania poziomu i struktury wykształcenia ludności Francji zamorskiej i metropolitalnej od lat 90. XX wieku po pierwszą dekadę XXI wieku. Uwzględniając wpływ funkcjonowania szkolnictwa na jakość zasobów ludzkich, w drugiej części artykułu dokonana zostanie próba regionalnego porównania wybranych wskaźników rozwoju przedsiębiorczości, głównie w aspekcie rozwoju gospodarki opartej na wiedzy i innowacyjności z wybranymi cechami obrazującymi zmiany zachodzące w szkolnictwie Francji zamorskiej. Podkreślić należy, że przedsiębiorczość i społeczeństwo nie funkcjonują w odosobnieniu, ale wykazują bardzo silne powiązania zarówno między sobą, jak i innymi elementami systemu społeczno-gospodarczego i kulturowego 
(Zioło 2009). W niniejszej pracy ograniczono się jedynie do przedstawienia zróżnicowania i zależności pomiędzy dwoma elementami: edukacją a kapitałem ludzkim w ujęciu ekonomicznym. Nie uwzględniono natomiast bardzo ważnych czynników, wpływających na poziom wykształcenia społeczeństw Francji zamorskiej i metropolitalnej, którymi są uwarunkowania kulturowe oraz poziom rozwoju i zamożności departamentów zamorskich.

W pracy wykorzystano dane statystyczne francuskich instytucji związanych z poszczególnymi szczeblami kształcenia (Ministère de l'éducation nationale, de la jeunesse et de la vie associative - MENJVA, Ministère de l'enseignement supérieur et de la recherche - MENESR, Centre d'études et de recherches sur les qualifications - CÉREQ) oraz dane publikowane przez francuski urząd statystyczny (Institut national de la statistique et des etudes économiques INSEE) i EUROSTAT.

Jak wspomniano, badaniem zostały objęte zarówno regiony Francji metropolitalnej, jak i powstałe w 1946 roku departamenty zamorskie, które w wyniku decentralizacji w 2003 roku uzyskały statut departamentów i regionów zamorskich ${ }^{2}$ (DROM - départements et régionsd' outre-mer), zrównujący je formalno-prawnie z regionami europejskimi. Wchodząc w skład UE, DROM zaliczane są do regionów peryferyjnych i podlegają przepisom prawa wspólnotowego (poza strefą Schengen i unią VAT).

\section{System ksztalcenia we Francji}

System edukacji jest ważnym czynnikiem warunkującym rozwój gospodarki każdego państwa; stymuluje wzrost gospodarczy, badania i innowacje, konkurencyjność oraz aktywne postawy obywatelskie (Bednarz 2007). Francuski system edukacyjny korzeniami sięga czasów Wielkiej Rewolucji i należy do historycznie najstarszych i najbardziej scentralizowanych w Europie. Ideę jego działania określa konstytucyjny zapis z 1958 roku, stanowiący, iż obowiązkiem państwa pozostaje świadczenie obligatoryjnej edukacji publicznej na wszystkich poziomach kształcenia. Zasada podejmowania obowiązku edukacyjnego od 6 do 16 roku życia została ostatecznie uregulowana w 1959 roku. Przewiduje ona dwie możliwości: zapisania dziecka do placówki publicznej lub prywatnej albo zapewnienie edukacji we własnym zakresie po uprzednim powiadomieniu władz oświatowych. Bezpłatna edukacja obejmuje okres szkoły elementarnej i średniej. Proces skolaryzacji finansowany ze środków Republiki jest wieloetapowy, zaś szereg cykli w poszczególnych jego fazach umożliwia elastyczne rozwijanie zainteresowań edukacyjnych.

System kształcenia we Francji składa się z pięciu poziomów. Pierwszy etap kształcenia obejmuje edukację na poziomie przedszkolnym (enseignement préélémentaire) i nie jest obowiązkowy. Uczestniczą w nim dzieci w wieku 3-6 lat. Podstawowym zadaniem etapu przedszkolnego jest przygotowanie jego uczestników do szkoły elementarnej. Obowiązkowa szkoła podstawowa (école élémentaire) składa się z 2 cykli: cycle des apprentissages fondamentaux - elementarnego - i będącego jego kontynuacją cycle des approfondissements. Edukację w szkole podstawowej może rozpocząć dziecko w wieku 5, 6 lub 7 lat, co zależne jest od opinii psychologa, lekarza, pracownika placówki oświatowej i rodziców. Promocja ucznia do klasy wyższej nie następuje w sposób automatyczny, a podejmowana jest przez grono nauczycielskie. Pięcioletni okres nauki w szkole podstawowej kończy się bez egzaminu, jednakże przeprowadzana jest ocena osiągnięć uczniów z języka francuskiego i matematyki (CE1 i CM2).

Ukończenie pięcioletniej szkoły elementarnej rozpoczyna drugi obowiązkowy etap kształcenia odbywający się w collège - gimnazjum. Jego uczestnikami są uczniowie w wieku

$\overline{2}$ W wyniku referendum w 2011 roku do DOM została włączona Majotta. 
11-15 lat, a realizowane w nim cykle trwają w sumie 4 lata. Podsumowaniem gimnazjalnego procesu edukacyjnego jest egzamin końcowy (Le diplôme national du brevet - DNB), obejmujący język francuski, historię i geografię Francji oraz matematykę. W dyplomie ukończenia wyszczególnieniu podlegają wszystkie oceny uzyskane przez ucznia w trakcie 2 ostatnich lat edukacji. Przystąpienie do kolejnego etapu kształcenia na poziomie szkolnictwa średniego przypadającego na wiek 15-18 lat nie jest uzależnione od zdania egzaminu kończącego gimnazjum (ryc. 1). Szkoła średnia 2 stopnia obejmuje 3 rodzaje placówek. Kształcenie ogólne trwające 3 lata odbywa się w liceum ogólnokształcącym (Lycée d'Enseignement Général $L E G$ ), liceum technicznym (Lycée d'Enseignement Technologique - LET) lub liceum zawodowym (Lycée Professionnel - LP).Uczeń podejmujący naukę w liceum decyduje się na tzw. kształcenie długie, natomiast edukacja w szkole zawodowej określana jest jako kształcenie krótkie.

Ryc. 1. System szkolnictwa średniego we Francji (liceum ogólnokształcące i techniczne)
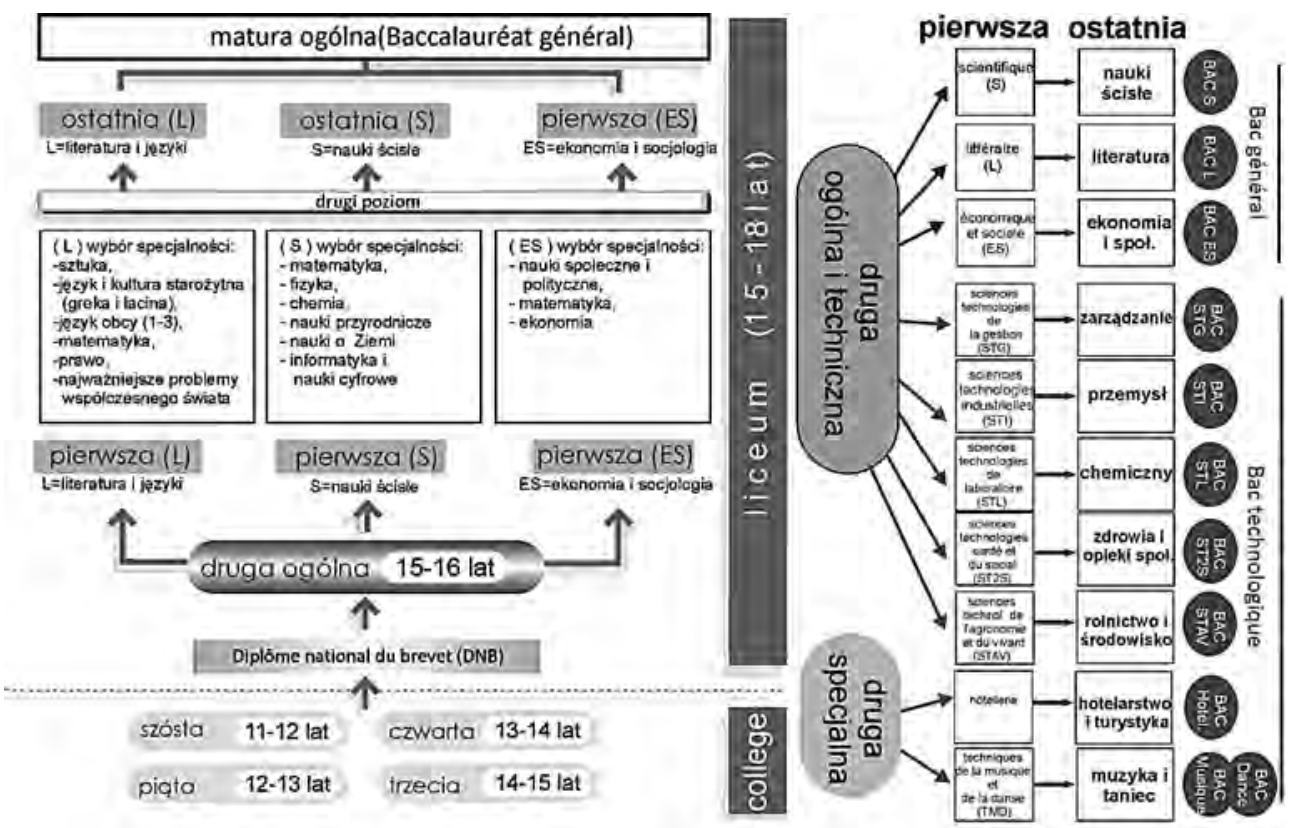

Źródło: opracowanie własne na podstawie materiałów MENJVA.

Na poziomie średnim odbywa się pierwsza specjalizacja. Po roku w klasie ogólnej uczeń wybiera 1 z 3 specjalizacji: humanistyczną, nauki ścisłe lub ekonomię i nauki społeczne. W liceach profilowanych specjalizacja dokonuje się z zakresu wybranej dziedziny gospodarki. Ukończenie szkoły licealnej zakończone jest egzaminem maturalnym (baccalauréat - Bac), który odbywa się według wybranej specjalizacji. W wypadku niezdania egzaminu dojrzałości, lecz uzyskania średniej oceny 8 pkt. na 20 możliwych, wydawane jest świadectwo ukończenia szkoły średniej, które jednak nie legitymizuje do podejmowania studiów. Absolwentom szkół zawodowych dana została możliwość uzyskania matury zawodowej, na którą składają się przedmioty kształcenia ogólnego uzupełnione o przedmioty zawodowe. W 1989 roku we francuskim prawie oświatowym wprowadzono zapis, w myśl którego matura zawodowa i ogólnokształcąca mają taką samą wartość. Absolwenci liceów zawodowych oprócz dyplomu 
potwierdzającego umiejętności zawodowe otrzymują świadectwo kwalifikacji zawodowych (brevet d'etudes professionnelles - BEP) oraz ewentualnie, po złożeniu egzaminu, dyplom zawodowy (baccalauréat professionnel - Bac pro) potwierdzający zdolność osoby do wykonywania wysoko wykwalifikowanej pracy w 96 specjalizacjach. Uzyskanie dyplomu otwiera możliwość kontynuowania nauki w szkole pomaturalnej kończącej się uzyskaniem tytułu technika (DUT). Daje także możliwość podjęcia dwuletnich specjalnych studiów technicznych (STS), a w konsekwencji - otrzymanie tytułu inżyniera. Matura zawodowa stanowi odpowiedź na zapotrzebowanie rynku pracy w zakresie nowych technologii oraz w dziedzinach związanych $\mathrm{z}$ automatyką i robotyką, informatyką przemysłową czy projektowaniem komputerowym. Należy przyjąć, że jedną z największych korzyści decyzji z 1989 roku jest wzrost poziomu umiejętności wysoko wykwalifikowanych pracowników. Podobnie absolwenci liceów technicznych otrzymują maturę techniczną, poszerzoną o wiedzę z wybranej dziedziny gospodarki. Okres przygotowania do egzaminu wynosi 2 lata, a jego uczestnicy zobligowani są również do odbycia praktyk w przedsiębiorstwie w wymiarze 16-20 tygodni. Szkolnictwo zawodowe umożliwia uzyskanie po 2 latach nauki certyfikatu kompetencji zawodowych (certificat d'aptitude professionnelle - CAP) lub po 4 latach nauki $(\mathrm{CAP}+2)$ dyplomu zawodowego (Bac pro) (ryc. 2).

Ryc. 2. System szkolnictwa zawodowego we Francji

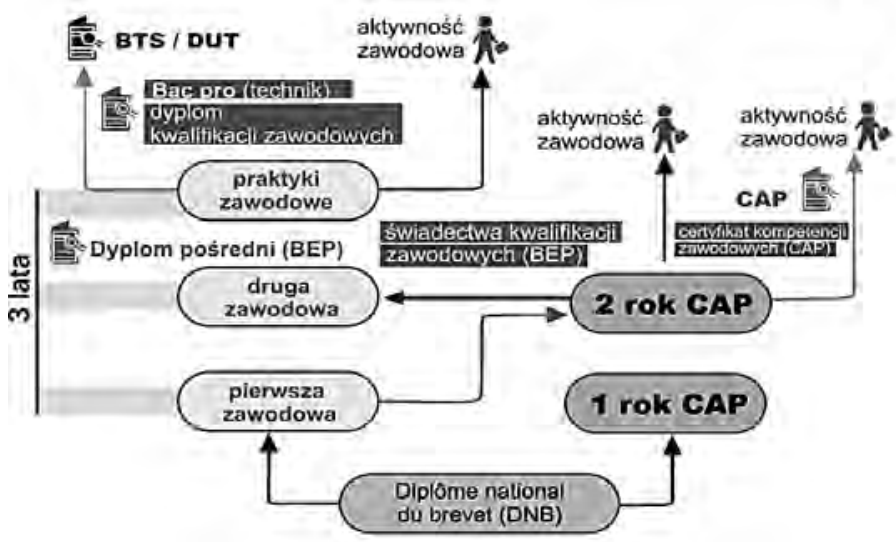

Źródło: opracowanie własne na podstawie materiałów MENJVA.

Zdany egzamin maturalny stanowi przepustkę na studia wyższe, zaś właściwa rekrutacja przeprowadzana jest po 1 roku kształcenia. Piąty cykl kształcenia odbywa się w różnych rodzajach szkół, wśród których można wyróżnić uniwersytety (w tym uniwersytety medyczne), instytuty techniczne (IUT), specjalne studia techniczne (STS) oraz specjalne szkoły wyższe, w tym kursy przygotowawcze do Grande école (CPGE). Pierwszy cykl studiów uniwersyteckich trwający 2 lata umożliwia uzyskanie dyplomu ${ }^{3}$ ogólnego - Dyplome d'Etudes Universitaires Gnrales (DEUG) i technicznego - Diplôme d'Etudes et Techniques Universitaires Scientifiques (DEUS). Około 40\% studentów kończy naukę na tym poziomie. Dyplom ten w niektórych

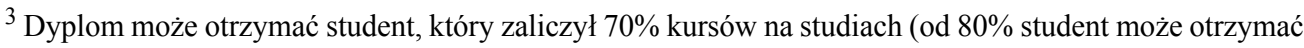
licencjat).
} 
przypadkach jest równoważny z uzyskaniem licencjatu (license), który jednakże czasami wymaga odbycia trzyletnich studiów. Tytuł magistra (maître - MA) można otrzymać po 2 latach nauki na kierunkach uniwersyteckich, jednakże tylko wybór studiów naukowych (a nie zawodowych) pozwala na kontynuowanie nauki na kursach w celu otrzymania tytułu doktora (ryc. 3). W poniższym opracowaniu ze względu na tematykę związaną z aktywnością gospodarczą mieszkańców podjęto analizę danych związanych z III, IV i V poziomem edukacji, który najsilniej wpływa na jakość kapitału ludzkiego.

Ryc. 3. System szkolnictwa wyższego we Francji

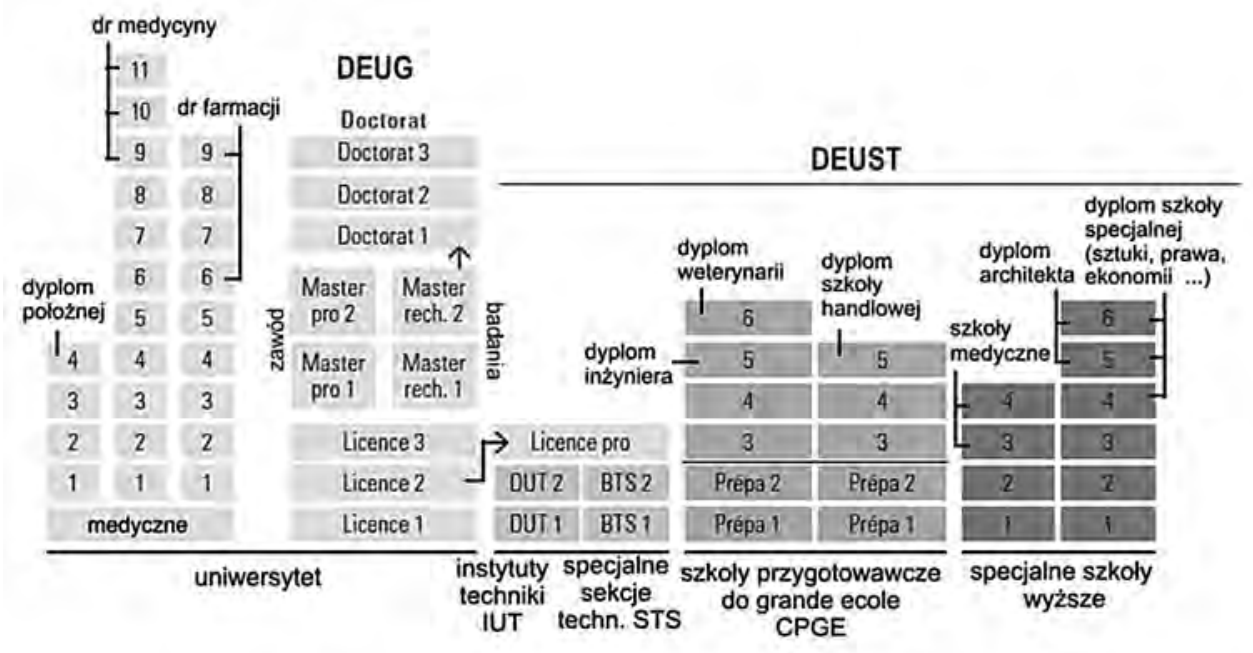

Źródło: opracowanie własne na podstawie materiałów MENESR.

System edukacyjny DOM stanowi odzwierciedlenie modelu metropolitalnego, niewielkie różnice powodowane są przez próby prowadzenia zajęć w języku kreolskim, uprzywilejowanym w stosunku do francuskiego. Silna presja demograficzna charakterystyczna dla DOM od lat 50. XX wieku w połączeniu z problemami edukacyjnymi stanowi podstawową przyczynę obecnych problemów społeczno-gospodarczych departamentów zamorskich, hamując tym samym rozwój przedsiębiorczości i innowacji w regionach. W ostatnim dziesięcioleciu poczyniony został jednak znaczny postęp w wyrównywaniu szans edukacyjnych.

\section{Regionalne zróżnicowanie potencjału edukacyjnego DOM i Francji metropolitalnej}

Za Borowiec (2008) można stwierdzić, że czynnikiem decydującym o kierunkach i poziomie rozwoju społeczno-ekonomicznego jest jakość funkcjonowania systemu nauki i szkolnictwa, który wpływa na jakość zasobów ludzkich w układach regionalnych i lokalnych. Zasoby intelektualne zależą również od potencjału demograficznego i poziomu rozwoju gospodarczego. Ludność departamentów zamorskich stanowi zaledwie ok. 3\% populacji Francji i 2\% siły roboczej. Wśród departamentów zamorskich największy udział w liczbie ludności Francji, jak i zatrudnienia, ma Réunion, natomiast najmniejszym potencjałem demograficznym 
charakteryzuje się Gujana (ryc. 4). Również udział wartości PKB departamentów zamorskich stanowi niecałe 2\% PKB Francji. Analizując zmiany wartości PKB w przeliczeniu na liczbę ludności i zatrudnionych, można zauważyć utrzymującą się od lat 90. XX wieku tendencję wzrostową obu wskaźników. Zauważyć należy, że średnioroczne tempo wzrostu produktu krajowego DOM jest większe niż dla regionów Francji metropolitalnej z pominięciem regionu stołecznego Île-de-France, który, skupiając ponad 27\% PKB kraju, zawyża średnie wskaźniki dla regionów europejskich Francji. Przyjmuje się, że obserwowany wzrost gospodarczy DOM wywołany jest zewnętrzną pomocą UE skierowaną do regionów najuboższych.

Ryc. 4. Ludność i pracujący w Francji metropolitalnej i zamorskiej w 2009 roku oraz zmiany wielkości PKB w latach 1990-2009

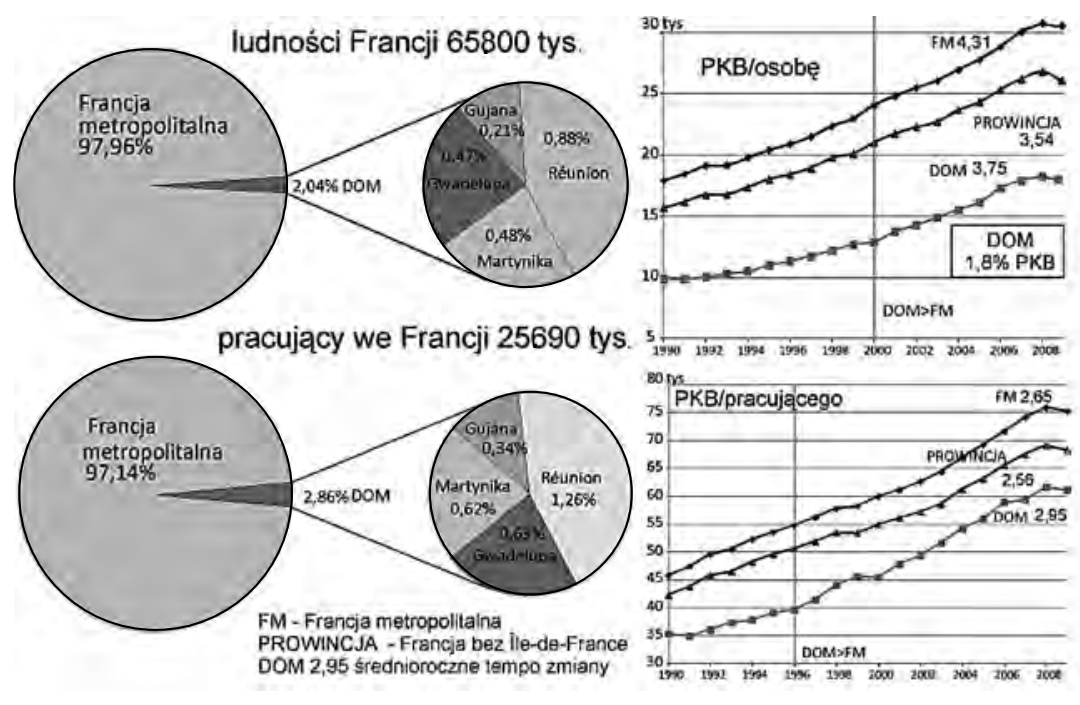

Źródło: opracowanie własne na podstawie INSEE.

Departamenty zamorskie Francji charakteryzuje nie tylko wysoki wzrost wartości PKB, lecz także wysokie tempo wzrostu liczby ludności. Wzrost liczby ludności DOM spowodowany jest głównie przez wysoki przyrost naturalny oraz, w wypadku Gujany, również przez dodatnie saldo migracji (ryc. 5A). Jednakże to młode społeczeństwo wciąż charakteryzuje się bardzo niskim poziomem wykształcenia. Prawie połowa ludności Francji zamorskiej powyżej 15 roku życia nie posiada żadnego wykształcenia lub posiada jedynie wykształcenie podstawowe, podczas gdy dla metropolii wskaźnik ten wynosi ok. 32\%. Sytuacja związana z wykształceniem społeczeństwa DOM ulega powolnej poprawie, lecz tempo zmian jest wciąż niższe niż we Francji metropolitalnej (ryc. 5B). Jedynie w Gujanie Francuskiej poziom wykształcenia populacji utrzymuje się wciąż na tym samym, niskim poziomie. 
Ryc. 5. Średnioroczne tempo zmiany liczby ludności w latach 1999-2008 (A) oraz udział ludności powyżej 15 roku życia posiadających wykształcenie podstawowe lub bez wykształcenia w regionach DOM w 1999 i 2006 roku (B)
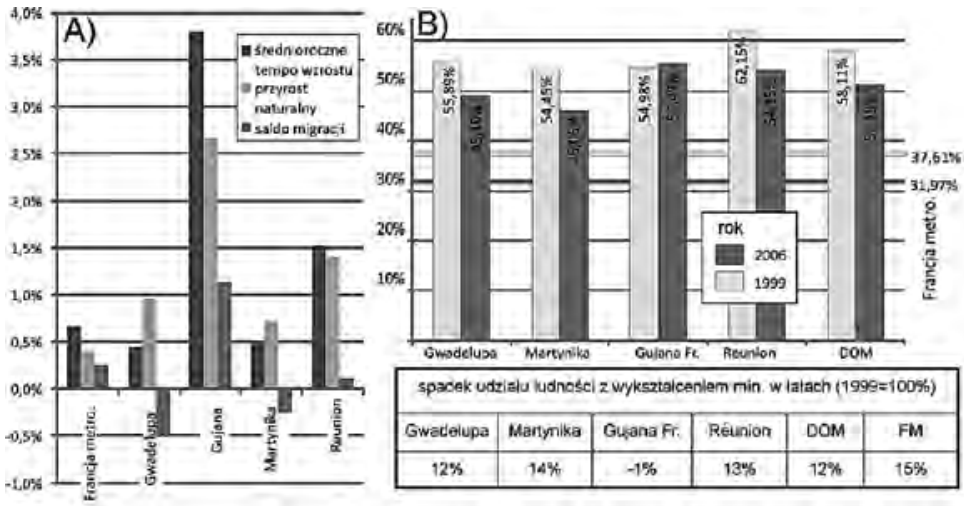

Źródło: opracowanie własne na podstawie INSEE.

Porównując regionalne zróżnicowanie udziału ludności powyżej 15 roku życia we wszystkich regionach Francji, można zauważyć, że pomiędzy rokiem 1999 a 2006 w układzie regionalnym nie zaszły wielkie zmiany (ryc. 6A). Regionami o najmniejszym udziale ludności bez wykształcenia (poniżej 31\% ogółu ludności) były regiony najbardziej rozwinięte gospodarczo położone na zachodzie i południu Francji: Île-de-France, Bretania, Alzacja, Rodan-Alpy, Midi-Pyrénées i Akwitania. Najgorsza sytuacja panowała w regionach północno-wschodnich Francji: Szampania, Pikardia i Dolna Normandia, gdzie udział ludności bez wykształcenia przekraczał 37\%. Największy wzrost udziału ludności z wykształceniem ponadpodstawowym w latach 1999-2006 odnotowały regiony zachodnie Francji (Bretania, Poitou-Charentes i Limousin) oraz Martynika i Réunion (ryc. 6B). Wzrost odnotowały zatem zarówno regiony o niskim, jak i wysokim udziale ludności bez wykształcenia. Jedynie w Gujanie Francuskiej nastąpił w badanym okresie wzrost udziału ludności z wykształceniem minimalnym. Podobnie niski wzrost odnotowały rozwinięte regiony z wysokim odsetkiem wykształconej ludności (Île-de-France, Alzacja i Prowansja).

Ryc. 6. Udział ludności powyżej 15 roku życia z wykształceniem podstawowym lub bez wykształcenia w regionach Francji $(A)$ oraz spadek udziału ludności z wykształceniem minimalnym w latach 1999-2006 (B)
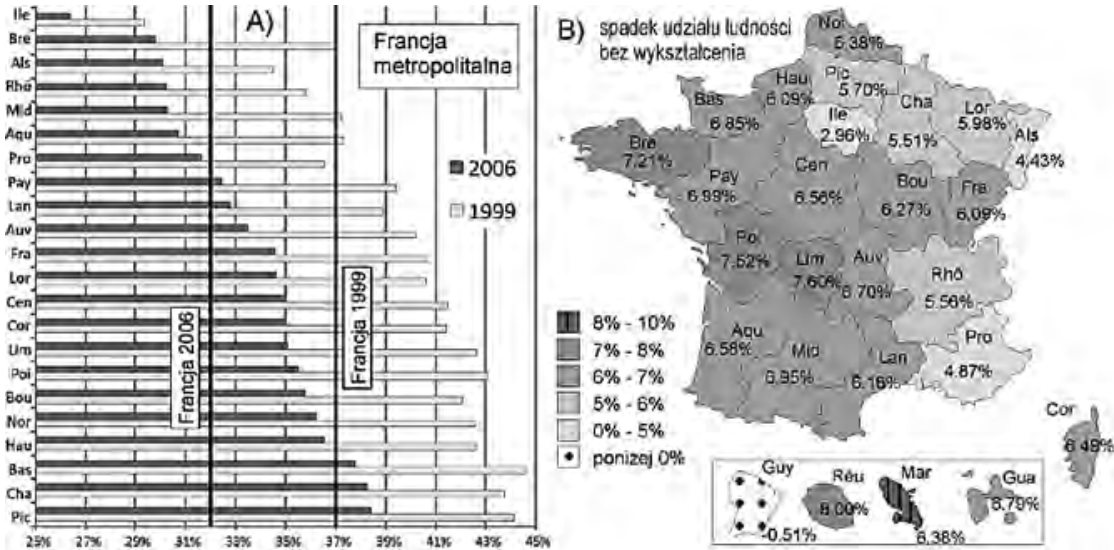

Źródło: opracowanie własne na podstawie CÉREQ. 


\section{Poziom edukacji według wieku uczniów}

Następnym wskaźnikiem aktywności społeczeństwa jest udział ludności kształcącej się w danej grupie wiekowej. We Francji obowiązkowa nauka trwa do 16 roku życia, dlatego podjęcie nauki w następnych latach świadczy o przedsiębiorczości uczniów i chęci podnoszenia swoich kwalifikacji. Kształcenie młodzieży rozpatrywano w 2 przedziałach wiekowych: 16-19 lat, czyli edukację na IV poziomie kształcenia, oraz 20-24 lata, czyli edukację obejmującą kształcenie policealne na $\mathrm{V}$ poziomie (ryc. 7). W obydwu przedziałach wiekowych większy odsetek młodzieży w latach kształci się we Francji metropolitalnej niż w zamorskiej. W wypadku podejmowania nauki w szkołach ponadgimnazjalnych różnica w udziale kształcącej się młodzieży pomiędzy metropolią a DOM wynosi zaledwie 5\%. Natomiast w wypadku kontynuowania nauki w wieku 20-24 lata różnica ta wynosi ponad 10\% na korzyść regionów europejskich. W obu wypadkach w okresie 1996-2007 różnice te nie uległy dużym zmianom, a redukcja zróżnicowania pomiędzy DOM a Francją metropolitalną wyniosła zaledwie kilka punktów procentowych. Spośród regionów zamorskich udział kształcących się w wieku 16-19 lat jest najmniejszy na Martynice, a najwyższy w Gujanie Francuskiej. W przedziale wiekowym 20-24 lata sytuacja uległa zmianie na rzecz Martyniki. Może to świadczyć o fakcie, że w Gujanie, w której jest niski poziom szkolnictwa, duża część młodzieży wykazuje większą aktywność edukacyjną na etapie progimnazjalnym. Uczniowie ci, wybierając szkoły zawodowe na tym poziomie, kończą swą edukację. Natomiast w lepiej rozwiniętej Martynice młodzież w większej części kontynuuje naukę po szkole średniej, wybierając tzw. długi model kształcenia. Zasadę tę potwierdzają dane dla pozostałych regionów Francji. Największy udział młodzieży kształcącej się w pierwszym przedziale wiekowym wykazują słabo rozwinięte regiony Masywu Centralnego lub Kraina Loary, podczas gdy w wypadku kształcenia się w wieku 20-24 lata na czołówkę wysuwają się rozwinięte regiony: Île-de-France, Środkowe Pireneje lub Bretania. Można zatem stwierdzić, że w regionach rozwiniętych gospodarczo występuje większa segregacja w zakresie powszechności kształcenia niż w regionach biedniejszych.

Ryc. 7. Udział ludności kształcącej się w danej grupie wiekowej w latach 1996-2007 oraz jego regionalne zróżnicowanie w 2007 we Francji

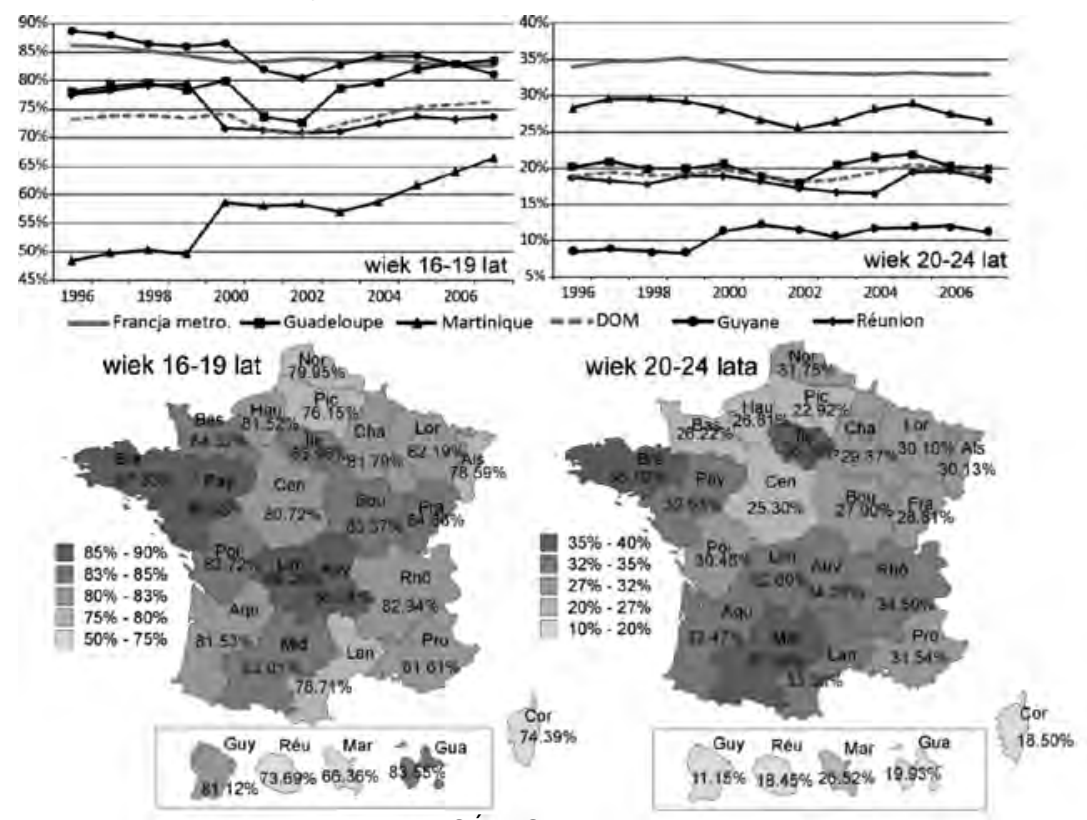

Źródło: opracowanie własne na podstawie CÉREQ. 


\section{Współczesna edukacja zawodowa}

Następnym kryterium charakteryzującym kształcenie we Francji jest udział osób w szkołach zawodowych (BEP, CAP) w stosunku do ogółu uczniów szkół ponadgimnazjalnych oraz jego zmiana w latach 1997-2007 (ryc. 8A). W departamentach zamorskich Francji ponad połowa uczniów podejmuje naukę w szkołach zawodowych, podczas gdy w metropolii udział ten kształtuje się na poziomie 47\%, wykazując w badanym okresie niewielki trend spadkowy. Następstwem tego procesu jest wzrost udziału uczniów w liceach w większości regionów Francji metropolitalnej. Niewielki (ok. jednoprocentowy) spadek udziału licealistów odnotowały natomiast regiony DOM (z wyjątkiem Réunion) oraz Korsyka, Limousin i północno-wschodnie regiony Francji związane z tradycyjnymi gałęziami przemysłu. W większości są to regiony charakteryzujące się wysokim (ponad 50\%) udziałem uczniów szkół zawodowych, co dodatkowo świadczy o niskim poziomie wykształcenia społeczeństwa. We Francji ponad połowa absolwentów szkół zawodowych decyduje się na kontynuowanie nauki w celu otrzymania dyplomu matury zawodowej (ryc. 8B). Różnica pomiędzy metropolią a regionami zamorskimi jest w tym wypadku niewielka i uległa w badanym okresie wyraźnemu zmniejszeniu. Odbyło się to głównie dzięki wysokiemu wzrostowi udziału osób kontynuujących naukę po szkole zawodowej w Réunion oraz niewielkiemu spadkowi w regionach metropolitalnych Francji, między innymi regionach Masywu Centralnego, Korsyce, Poitou-Charentes i Île-deFrance. W obu analizowanych cechach szkolnictwa zawodowego we Francji lepszymi wskaźnikami wyróżniają się regiony zachodnie (Bretania, Kraina Loary) i południowo-zachodnie Francji (Akwitania, Środkowe Pireneje).

Ryc. 8. Udział osób w szkołach zawodowych (BEP, CAP) w stosunku do ogółu uczniów szkół ponadgimnazjalnych i jego zmiana (A) oraz udział uczniów kontynuujących naukę po szkołach zawodowych (Bac pro) i jego zmiana (B) we Francji
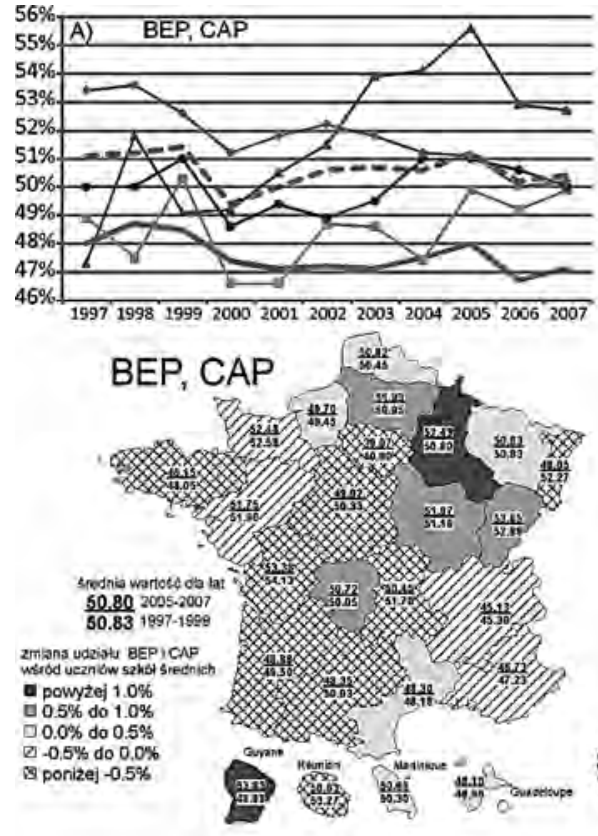
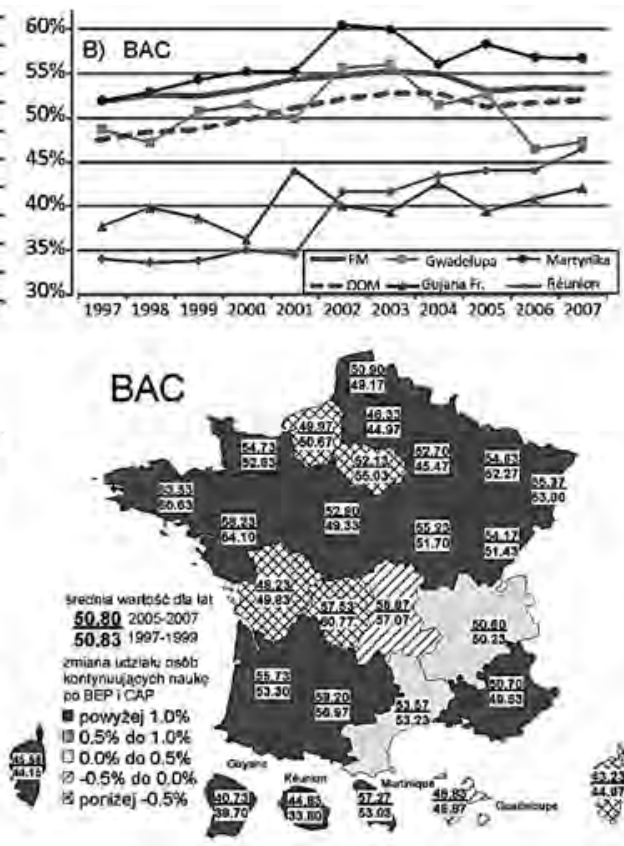

Źródło: opracowanie własne na podstawie CÉREQ. 
Przeprowadzona powyżej analiza regionalnego zróżnicowania czwartego poziomu szkolnictwa we Francji i zachodzących w nim zmian odnosiła się jedynie do udziału uczniów w poszczególnych rodzajach szkół. Nieporuszona została kwestia wyników nauczania. Dlatego w dalszych rozważaniach zostaną zgłębione zagadnienia promocji uczniów oraz uzyskania dyplomu przez absolwentów szkół zawodowych. Analizując zatem udział uczniów kończących collège w wieku powyżej 16 lat, można zauważyć, że w wypadku departamentów zamorskich udział uczniów powtarzających klasę w okresie 1990-2008 zmalał z 34\% do 10\% (ryc. 9A). W tym samym okresie wskaźnik ten dla metropolii zmalał z 20\% do 5\%, a różnica pomiędzy Europą a DOM zmalała prawie o 10\%. Spośród wszystkich regionów największy odsetek uczniów nie otrzymał promocji przynajmniej raz w trakcie nauki w Gujanie Francuskiej (ok. 30\%), podczas gdy na kontynencie najgorszą sytuację odnotowano w Szampanii, Górnej Normandii i Franche-Comté (powyżej 18\%). Najmniejszy (poniżej 13\%) udział mają natomiast rozwinięte regiony: Rhône-Alpes, Alzacja i Nord-Pas-de-Calais. Pomiędzy udziałem uczniów nieotrzymujących promocji a tempem zmian udziału zachodzi wyraźna korelacja (ryc. 9). W regionach o największym udziale uczniów powtarzających klasę można zauważyć najwyższe tempo spadku tego wskaźnika. Sytuacja ta świadczy o zmniejszaniu się międzyregionalnych dysproporcji w szkolnictwie lub o bardziej pobłażliwych kryteriach promocji uczniów. Inną cechą mogącą świadczyć o jakości nauczania jest odsetek osób kończących szkoły zawodowe bez uzyskania certyfikatu kompetencji zawodowych (CAP) lub świadectwa kwalifikacji zawodowych (BEP) (ryc. 9B). Podobnie jak w poprzednim wskaźniku udział uczniów kończących naukę bez uzyskania minimalnego poziomu kwalifikacji zawodowych jest większy w wypadku Francji zamorskiej i wynosi ok. 10\%; w regionach europejskich wskaźnik ten stanowi ok. 5\%. Jednocześnie od początku XXI wieku można zaobserwować spadek udziału absolwentów bez wykształcenia, który dla DOM wynosi ok. 5\%, a dla Francji metropolitalnej - 2\%. Również w tym wypadku można dopatrzeć się trendu zmniejszenia międzyregionalnego zróżnicowania poziomu wykształcenia.

Ryc. 9. Udział uczniów powyżej 16 roku życia kończących collège (A) oraz udział uczniów szkół zawodowych bez uzyskania minimalnego wykształcenia (CAP lub BEP) we Francji (B)
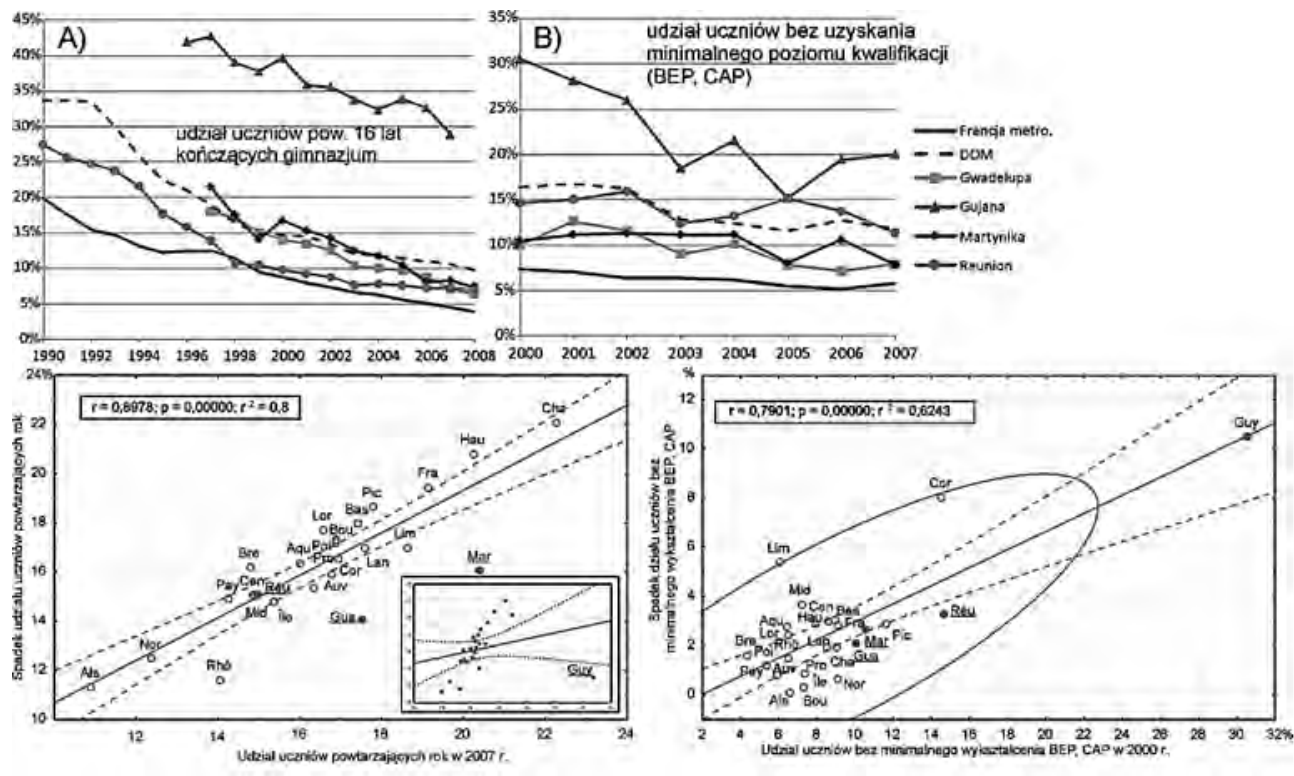

Źródło: opracowanie własne na podstawie CÉREQ. 


\section{Szkolnictwo średnie ogólnokształcące}

Analizując strukturę kształcenia ponadgimnazjalnego, szczególne miejsce należy poświecić udziałowi uczniów podejmujących tzw. długie kształcenie, w wyniku którego mogą one uzyskać dyplom maturalny, uprawniający do kontynuowania nauki na studiach. Udział maturzystów w swojej grupie wiekowej od połowy lat 90. XX wieku we Francji metropolitalnej utrzymuje się prawie na niezmiennym poziomie $60 \%$ (ryc. 10). Natomiast w DOM udział ten ulegał wahaniom, osiągając maksimum pod koniec XX wieku (59\%), by w 2005 roku spaść do poziomu $51 \%$. Związane to było głównie ze spadkiem liczby maturzystów na Martynice i Gwadelupie (spadek do poziomu 60\%). Spośród departamentów zamorskich jedynie w Gujanie nastąpił wyraźny wzrost ich udziału z 22\% do $31 \%$.

Ryc. 10. Zmiana udziału maturzystów w swojej grupie wiekowej w regionach DOM i we Francji w latach 1993- 2005 oraz jego regionalny rozkład
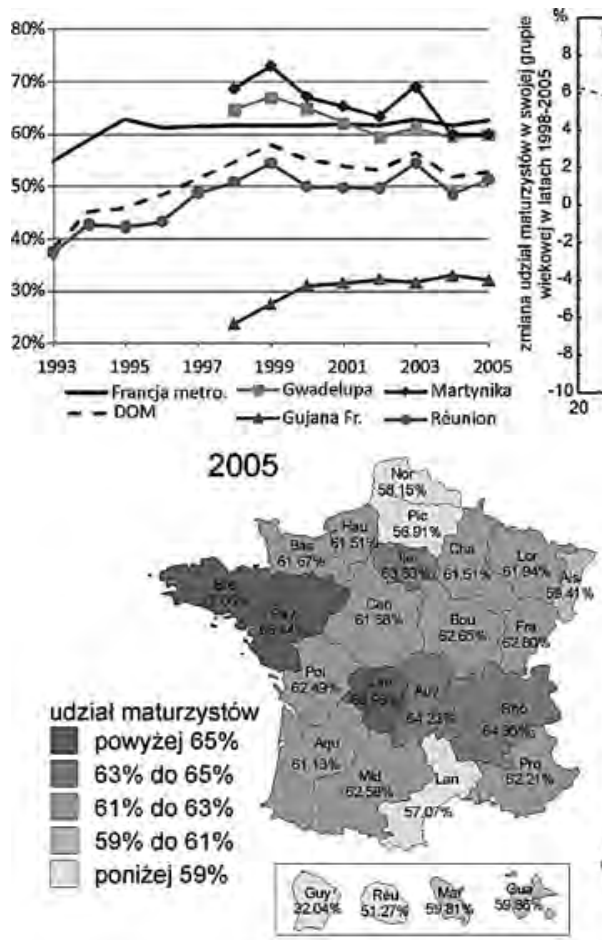
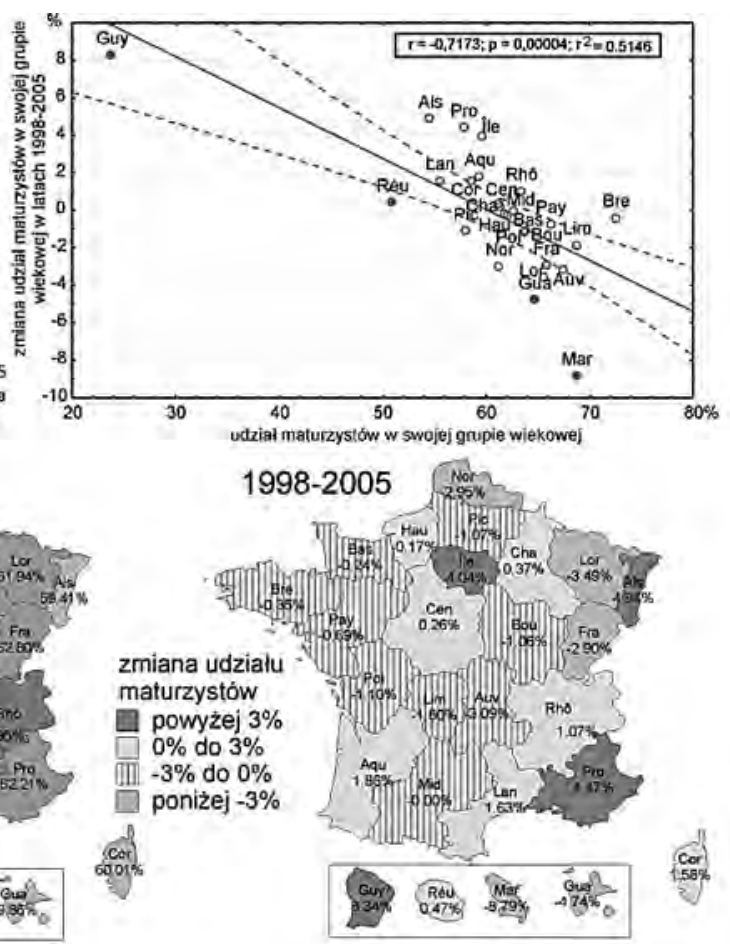

Źródło: opracowanie własne na podstawie CÉREQ.

W układzie regionalnym Francji kontynentalnej największy (powyżej 63\%) udział maturzystów w 2008 roku miały: Bretania (72\%), Limousin (67\%) Kraj Loary (65\%), Owernia oraz regiony Rodan-Alpy (64\%) i stołeczny (63\%). Najmniejszy (poniżej 60\%) odsetek odnotowano natomiast w Pikardii, Langwedocji i Nord-Pas-de-Calais. W okresie od 1998 do 2005 roku wzrost udziału maturzystów powyżej 4\%odnotowały rozwinięte regiony Alzacji, Prowansji i Île-de-France oraz zamorska Gujana, w której nastąpił wzrost o ponad 8\%. Ogólnie wzrost udziału maturzystów odnotowały głównie regiony południowe (poza regionem Midi-Pyrénées, w którym udział maturzystów pozostał prawie na niezmienionym poziomie) oraz regiony Basenu Paryskiego. Istnieje zatem słaba ujemna zależność pomiędzy udziałem maturzystów 
w 1998 roku a tempem jego zmiany do 2005 roku. Powielony zostaje proces niwelowania międzyregionalnych różnic w poziomie kształcenia społeczeństwa we Francji, chociaż dysproporcje pomiędzy DOM a metropolią są wciąż znaczące.

Innym ważnym kryterium wykształcenia, wpływającym na aktywność zawodową, w aspekcie konkurencyjności regionów, jest rodzaj i specjalizacja matury. We Francji udział maturzystów od połowy XIX wieku wykazuje tendencję wzrostową (ryc. 11A1). W latach 60. XX wieku zaczął wyraźnie wzrastać udział matur technicznych, a od końca lat 80. - matur zawodowych. Zmiany te były związane z procesem industrializacji, a następnie z procesem postindustrialnym, które to zwiększyły zapotrzebowanie na wykwalifikowaną i zróżnicowaną siłę roboczą. Współcześnie matury ogólne (Bac général) stanowią ok. 54\% wszystkich matur. Wśród matur technicznych (24\% ogółu matur) wydaje się, że największy wpływ na rozwój gospodarczy i zwiększenie konkurencyjności na rynku pracy mają matury ze specjalności przemysłowej (STI), chemicznej (STL) oraz ekonomii i zarządzania (SMS). Pod koniec XX wieku udział powyższych specjalności wśród matur w wypadku metropolii i DOM był zbliżony i wynosił ok. 30\% matur technicznych (ryc. 11A2). W następnych latach udział ten zaczął maleć, by w 2008 roku osiągnać poziom 26\% w wypadku metropolii i $28 \%$ w regionach zamorskich. Niższy spadek w DOM był spowodowany wysokim wzrostem udziału STI, STL i SMS w Gujanie i na Gwadelupie. Ogólnie pod koniec badanego okresu we wszystkich departamentach zamorskich udział tego rodzaju matur był wyższy niż dla Francji metropolitalnej. Spośród regionów Francji w Europie najwyższym udziałem ( $>27 \%$ ) charakteryzowały się dawne regiony przemysłowe (np. Nord-Pas-de-Calais, Pikardia, Lotaryngia, Franche-Comté Górna Normandia) i regiony rozwijające się (np. Korsyka, Limousin) oraz Bretania i Langwedocja, opierające swój rozwój na sektorze $\mathrm{B}+\mathrm{R}$. Analizując natomiast regionalną dynamikę udziału powyższych specjalności, można zauważyć ogólny trend spadkowy (z wyjątkiem Gujany, Korsyki i Langwedocji), który miał najniższą wartość w regionach południowo-wschodnich Francji, Alzacji oraz na Martynice i Gwadelupie (ryc. 11B2). Zaistniała sytuacja może świadczyć o potrzebie zatrudnienia bardziej wykwalifikowanej kadry pracowniczej związanej z wykształceniem wyższym, zwłaszcza w regionach przemysłowych oraz rozwijających się oraz o spadku znaczenia przemysłu w regionach rozwiniętych gospodarczo.

Ryc. 11. Zmiana udziału maturzystów w swojej grupie wiekowej wg rodzaju matury (A1) i specjalizacji (STI, SMS, STL ${ }^{4}$ ) w ogóle matur technicznych (Bac tech) (A2) oraz ich udział (B1) i zmiana (B2) w DOM i we Francji

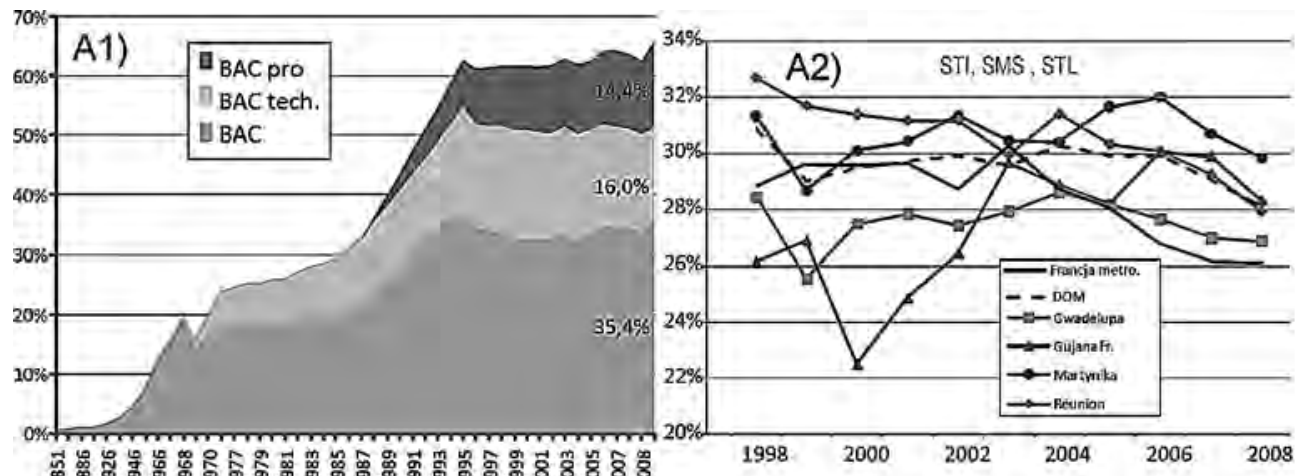

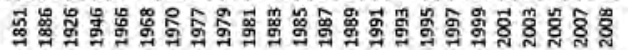
${ }^{4}$ Na początku 2011 roku specjalizację podzielono na: biotechnologię, fizykę stosowaną i laboratorium
chemiczne. 

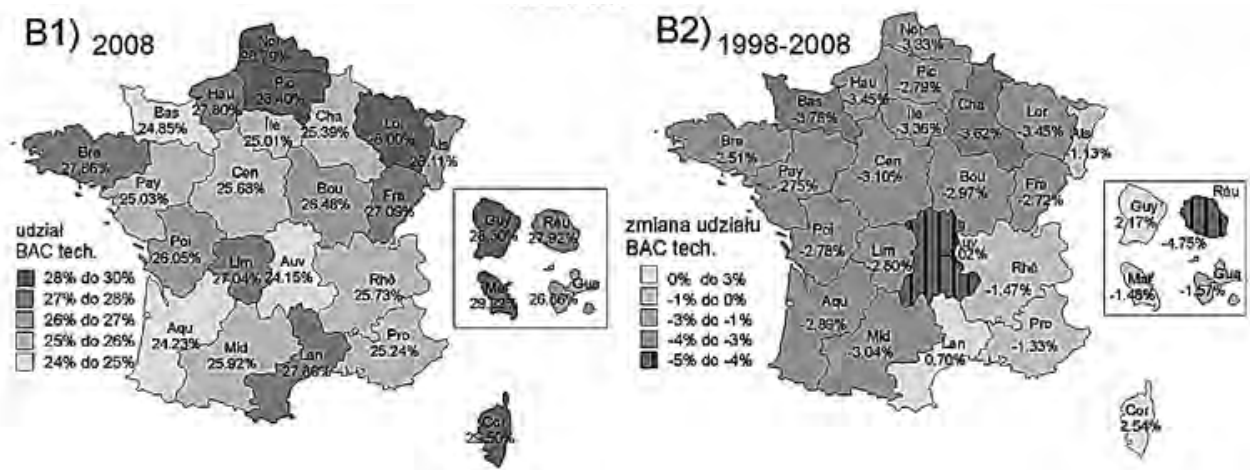

Źródło: opracowanie własne na podstawie CÉREQ.

Na zakończenie tej części dokonano próby ustalenia jakości kształcenia na poziomie średnim w regionach Francji. W tym celu zestawiono udział pozytywnych wyników egzaminów maturalnych dla departamentów zamorskich i Francji metropolitalnej. Przed przystąpieniem do właściwej analizy efektów kształcenia na poziomie IV odniesiono się do wiedzy nabytej w szkole podstawowej. To właśnie na I etapie kształcenia przekazywane są wiedza i umiejętności, które stanowią fundament dalszej ścieżki kształcenia. Porównując średnie wyniki osiągnięć uczniów po szkole podstawowej z matematyki i języka francuskiego dla lat 2009-2011 w DOM ze średnią ocen dla Francji metropolitalnej, można zaobserwować wyraźną przewagę Europy nad byłymi koloniami (ryc. 12). Szczególnie widoczne jest to w wypadku wyników z matematyki, przedmiotu, który w znaczącym stopniu wpływa na decyzję o wyborze kierunku dalszej nauki. W departamentach zamorskich ocenę bardzo dobrą otrzymało ok. 16\% mniej uczniów, równocześnie 19\% uczniów więcej niż w Europie otrzymało ocenę niedostateczną. W wypadku języka francuskiego sytuacja była podobna. Spośród departamentów zamorskich najgorsza sytuacja panuje w Gujanie Francuskiej. Można zatem stwierdzić, że młodzież departamentów zamorskich posiada gorsze wykształcenie już na początku nauki niż młodzież w Europie. Równie niepokojący jest fakt, że dysproporcje te nie wykazują tendencji malejącej, a wręcz przeciwnie, dysonans pomiędzy wynikami Europy a wynikami regionów zamorskich Francji w badanym okresie wciąż wzrastał.

Ryc. 12. Średni udział ocen uczniów z matematyki i j. francuskiego (CE1 i CM2) dla DOM w latach 2009-2011, w porównaniu ze średnimi ocenami dla Francji metropolitalnej

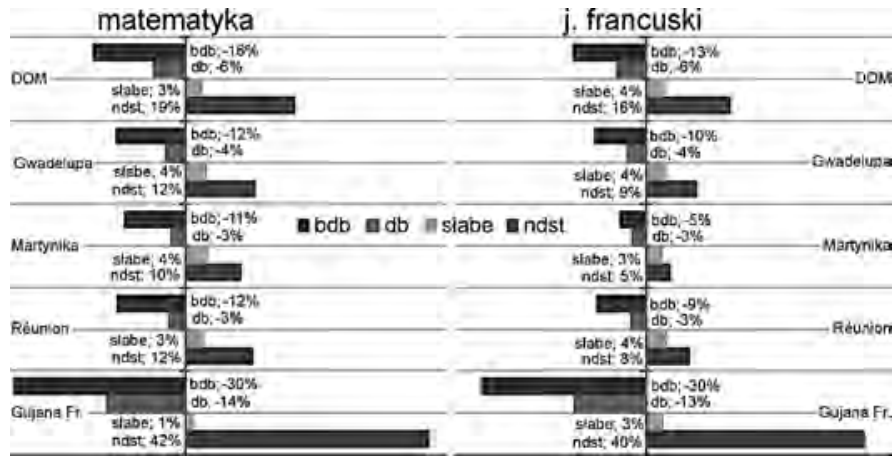

Źródło: opracowanie własne na podstawie danych MENJVA. 
Skutkiem słabszego przygotowania podstawowego uczniów w departamentach zamorskich były gorsze wyniki nauki otrzymane w szkole średniej niż w wypadku Francji metropolitalnej (ryc. 13). Porównując udział pozytywnych wyników matur w DOM, jedynie w Réunion, w przypadku matury technicznej i nauk ścisłych (Bac tech. i Bac S), ich udział był zbliżony lub przekraczał średni wskaźnik dla metropolii. Ogólnie udział pozytywnych wyników matury w regionach zamorskich był o 10\% niższy niż w metropolii. Najgorsza sytuacja wystąpiła w Gujanie oraz na Martynice, choć należy zauważyć, że w regionach tych w obydwu badanych latach nastąpił największy wzrost w zdawalności egzaminu.

Ryc. 13. Udział pozytywnych wyników egzaminu maturalnego ogólnego (Bac gen.) i technicznego (Bac tech.) dla DOM w 2005 i 2006 roku oraz udział pozytywnych wyników egzaminu maturalnego ze specjalizacji: nauki ścisłe (Bac S) oraz przemysł i chemia (Bac STI, STL) w 2006 roku dla DOM
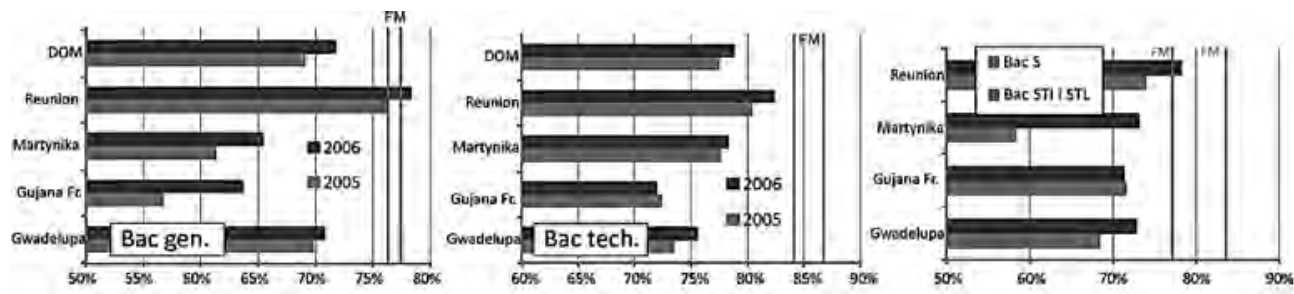

Źródło: opracowanie własne na podstawie danych CÉREQ.

\section{Edukacja szczebla wyższego}

Następnym etapem kształcenia w systemie edukacji Francji są studia w szkołach pomaturalnych i uczelniach wyższych. To właśnie szkolnictwo wyższe jest współcześnie postrzegane jako najważniejszy czynnik kształtowania potencjału regionów w aspekcie rozwoju gospodarki opartej na wiedzy i budowy potencjału kapitału ludzkiego (Borowiec 2007). W konsekwencji stymulowanie inwestycji w kapitał ludzki pozwala na stopniowe zmniejszanie się różnic w poziomie rozwoju regionalnego (Świtała 2007).

Na tym etapie badań wykorzystano dane odnoszące się do liczby studentów w poszczególnych placówkach szkół wyższych oraz struktury tych szkół (wg ich typów) w regionach zamorskich, a także liczby studentów w placówkach szkolnictwa wyższego zlokalizowanych w regionach Francji metropolitalnej. We Francji jest około 521 uczelni, z czego tylko 2 uniwersytety zlokalizowane są na obszarze DOM $^{5}$. Pierwszym z nich jest uczelnia z Gujany Francuskiej Université des Antilles et de la Guyane, w skład której wchodzą między innymi Institut Universitaire de Technologie (IUT) w Kourou, dział marketingu technicznego w Kajennie, Wydział Zarządzania i Administracji oraz Wydział Inżynierii Biologicznej w Saint-Claude (Gwadelupa), Wydział Bezpieczeństwa i Higieny Środowiska, Wydział Zarządzania, Logistyki i Transportu na Martynice, Wydział Elektrotechniki i Informatyki oraz Sieci i Telekomunikacji w Kourou (Gujana Francuska). Ponadto w Gujanie Francuskiej, na Gwadelupie i Martynice zlokalizowane są uczelnie pedagogiczne IUFM. Drugi uniwersytet znajduje się w Réunion (Université de la Réunion), gdzie jedyną jednostką zależną jest IUT w Saint-Pierre.

W okresie 1999-2010 we wszystkich regionach Francji zamorskiej odnotowano wzrost liczby studentów o ok. 25\%, natomiast we Francji metropolitalnej wynosił on ok. 8,6\%, a z wyłączeniem regionu paryskiego - 7,6\% (ryc. 15). Tak duży wzrost w DOM nastąpił głównie

\footnotetext{
${ }^{5}$ Więcej o ośrodkach akademickich jako czynniku podnoszenia jakości zasobów kapitału ludzkiego w układach regionalnych Francji można znaleźć w: Borowiec, Dorocki 2010.
} 
w wyniku znacznego przyrostu liczby studentów w Gujanie Francuskiej (125\%), podczas gdy w pozostałych regionach zamorskich wahał się on od 15\% na Martynice do 30\% na Gwadelupie. Tak wielki wzrost jest wynikiem uwarunkowań demograficznych, jak i ekonomiczno-społecznych. Zaznaczyć należy, że studenci DOM stanowią zaledwie ok. 1,6\% ogółu studentów Francji i ich udział porównywalny jest jedynie z Korsyką lub Limousin (ryc. 14). Porównując regionalny udział studentów we Francji oraz tempo jego zmiany można zauważyć, że regiony zamorskie charakteryzuje niska liczba studentów i wysoki wzrost. Najlepiej ilustruje to zestawienie obydwu wskaźników dla regionów Île-de-France i Gujany Francuskiej, znajdujących się w tym ujęciu po dwóch przeciwnych biegunach szkolnictwa wyższego Francji (ryc. 14).

Ryc. 14. Udział studentów w regionach Francji w roku 1999 i 2010 oraz wartość ich zmiany (1999=100\%)
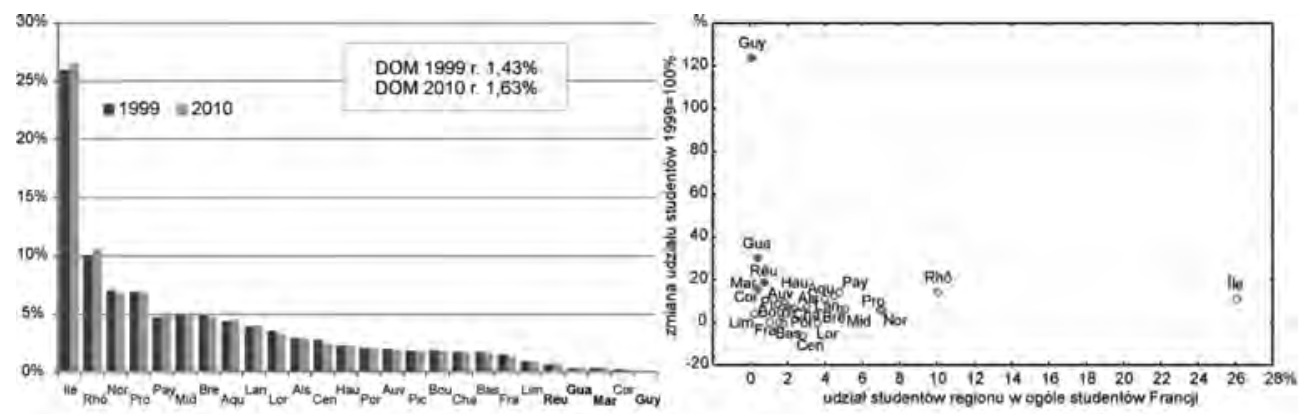

Źródło: opracowanie własne na podstawie danych z Atlas régional: les effectifs d'étudiants.

Ryc. 15. Zmiana liczby studentów poszczególnych rodzajów szkół wyższych w DOM i Francji metropolitalnej (FM) w latach 1999-2010 (1999 = 100\%)
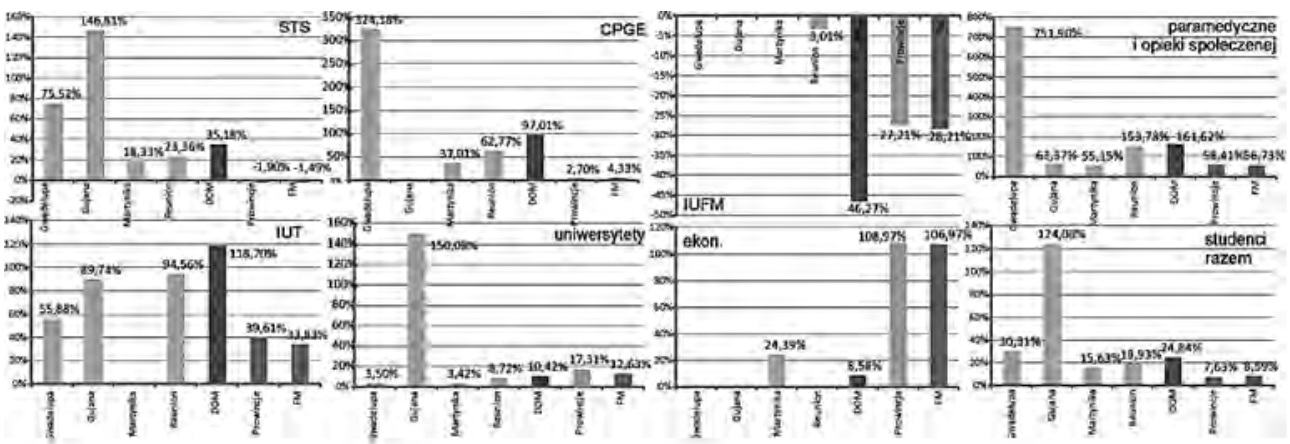

STS (sections de techniciens supérieurs) - sekcje dla dyplomowanych techników, krótkie studia techniczne IUT (Instituts Universitaires de Technologie) - uniwersyteckie instytuty technologiczne

CPGE (classes préparatoires aux grand écoles) - kursy przygotowawcze dla kandydatów do grande école IUFM (Instituts de Formation des Maîtres) - szkoły nauczycielskie, od 2005 roku połączone $z$ uniwersytetami

Źródło: opracowanie własne na podstawie danych z Atlas régional: les effectifs d'étudiants. 
Wśród rodzajów szkół wyższych w departamentach zamorskich Francji największy wzrost liczby studentów (ponad 100\%) odnotowano w szkołach związanych z opieką medyczną i społeczną (ok. 161\%) oraz w uniwersyteckich instytutach technologicznych (ok. 119\%) (ryc. 15). Zmiany te były zgodne z trendami we Francji metropolitalnej, w której wzrost w obu wypadkach wyniósł ok. 57\% i 34\%. Następnymi wg kolejności wzrostu studentów w DOM były kursy przygotowawcze do grande école (97\%) i krótkie studia techniczne (35\%), podczas gdy we Francji metropolitalnej w wypadku STS nastąpił spadek o 1,5\%, a w wypadku CPGE wzrost o niecałe 4,5\%. Wzrost liczby studentów uniwersytetów w wypadku Francji zamorskiej i metropolitalnej był podobny (odpowiednio 10,4\% i 12,6\%). W wypadku szkół ekonomicznych $\mathrm{w}$ regionach europejskich wzrost wyniósł ponad $100 \%$, podczas gdy w regionach zamorskich tylko 8,6\%. Dla szkół pedagogicznych na kontynencie spadek liczby studentów wyniósł 28\%, a w departamentach zamorskich - ponad $46 \%$. W większości rodzajów uczelni tak wysoki wzrost w DOM spowodowany był zwiększeniem się liczby studentów na Gwadelupie i w Gujanie, gdzie wysoki wzrost powodowała mała liczba słuchaczy uczelni pod koniec XX wieku.

Analizując udział studentów poszczególnych typów uczelni w strukturze regionów, można zauważać dominującą rolę uniwersytetów (ok. 60\%), jednakże z wciąż malejącym ich udziałem zarówno we Francji metropolitalnej, jak i zamorskiej. Spadek udziału we wszystkich regionach odnotowały również uczelnie pedagogiczne. W obu wypadkach spadek udziału w DOM był ponad dwukrotnie większy niż w Europie. Natomiast we Francji metropolitalnej spadek odnotowały również STS (krótkie studia techniczne). Największy wzrost udziału w ogóle studentów regionu w DOM miały inne uczelnie, czyli uczelnie kierunkowe oraz szkoły opieki medycznej i społecznej, podczas gdy na kontynencie były to uczelnie ekonomiczne i paramedyczne. Ogólnie w DOM w porównaniu z metropolią o 7\% większy był udział STS oraz o 2,5\% innych uczelni, podczas gdy na kontynencie wyraźnie większe znaczenie miały IUT, szkoły ekonomiczne i artystyczne, czyli instytucje bardziej zróżnicowane, które w większym stopniu mogą wpływać na innowacyjność gospodarki regionu w ujęciu klasy kreatywnej.

Ryc. 16. Zmiana liczby studentów poszczególnych rodzajów szkół wyższych w DOM i Francji metropolitalnej (FM) w latach 1999-2010 (1999 = 100\%)
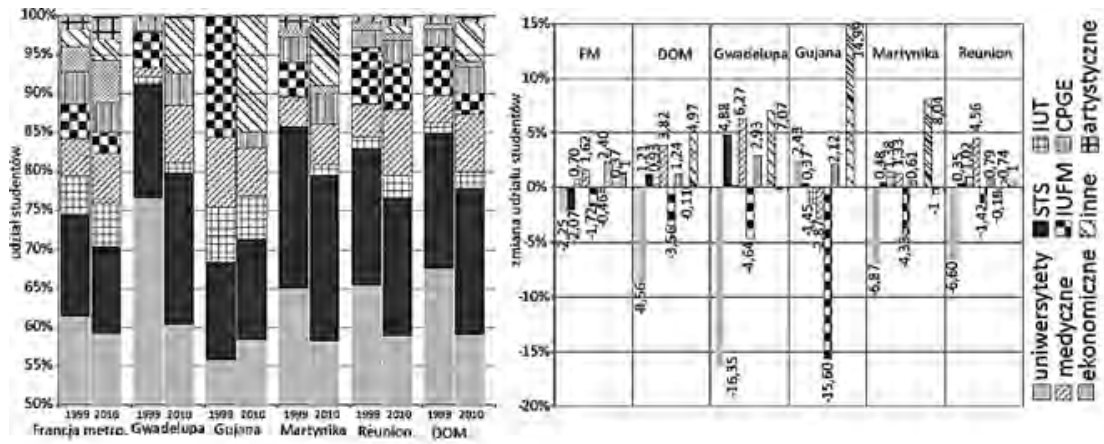

Źródło: opracowanie własne na podstawie danych z Atlas régional: les effectifs d'étudiants.

Porównując zmiany udziału studentów w latach 1992-2008 w różnego typach szkół wyższych wg ich lokalizacji, można zauważyć wyraźny spadek udziału studentów uniwersytetów oraz utrzymujący się z kilkuprocentową tendencją wzrostową udział studentów sekcji dla dyplomowanych techników (ryc. 17A). W obu przypadkach większy udział studentów w tych typach uczelni odnotowano w regionach DOM. W innych typach szkół: CPGE i IUT oraz 
w pozostałych typach większy udział studentów odnotowano w metropolii, choć trend wzrostowy w badanym okresie prawie nie przekroczył progu $12 \%$. Wyraźnie wzrastająca różnica wystąpiła jedynie w wypadku tzw. innych studiów, czyli studiów kierunkowych. W wyniku małego udziału prowadzących je uczelni społeczeństwa regionalne pozostają w zasadzie słabo wykształcone, co w szczególności dotyczy zawodów specjalistycznych (Simonin, Wolff 1992). W odniesieniu do wszystkich rodzajów studiów szybszą zmianą wykazywały się regiony DOM. Najszybszy wzrost udziału studentów w departamentach zamorskich Francji nastąpił dla uniwersyteckich instytutów technicznych (ok. 170\%) i CPGE (120\%), w tym zwłaszcza dla uniwersytetu w Gujanie (ryc. 17B).

Ryc. 17. Zmiana udziału liczby studentów szkół wyższych w uczelniach DOM i Francji metropolitalnej w latach 1992-2008 (A) i w regionach Francji $(1992$ = 100\%) (B) oraz zmiana udziału uzyskanych stopni naukowych na uczelniach w odniesieniu do ogółu studentów danego poziomu edukacyjnego w regionach FM i DOM w latach 2004-2008 (C)
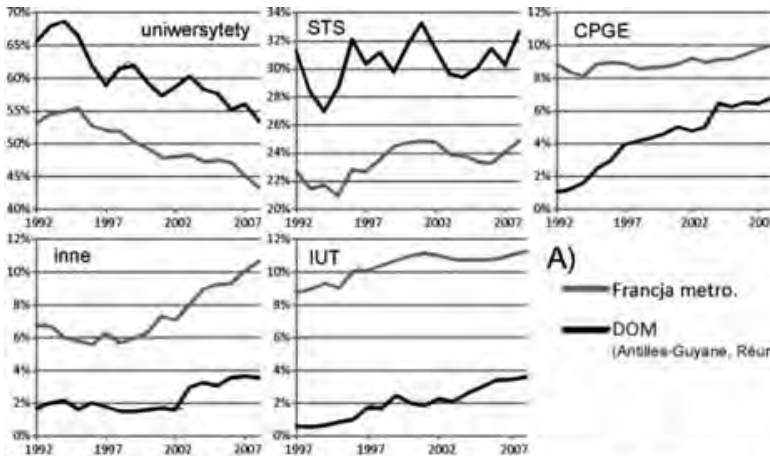

A)

B)
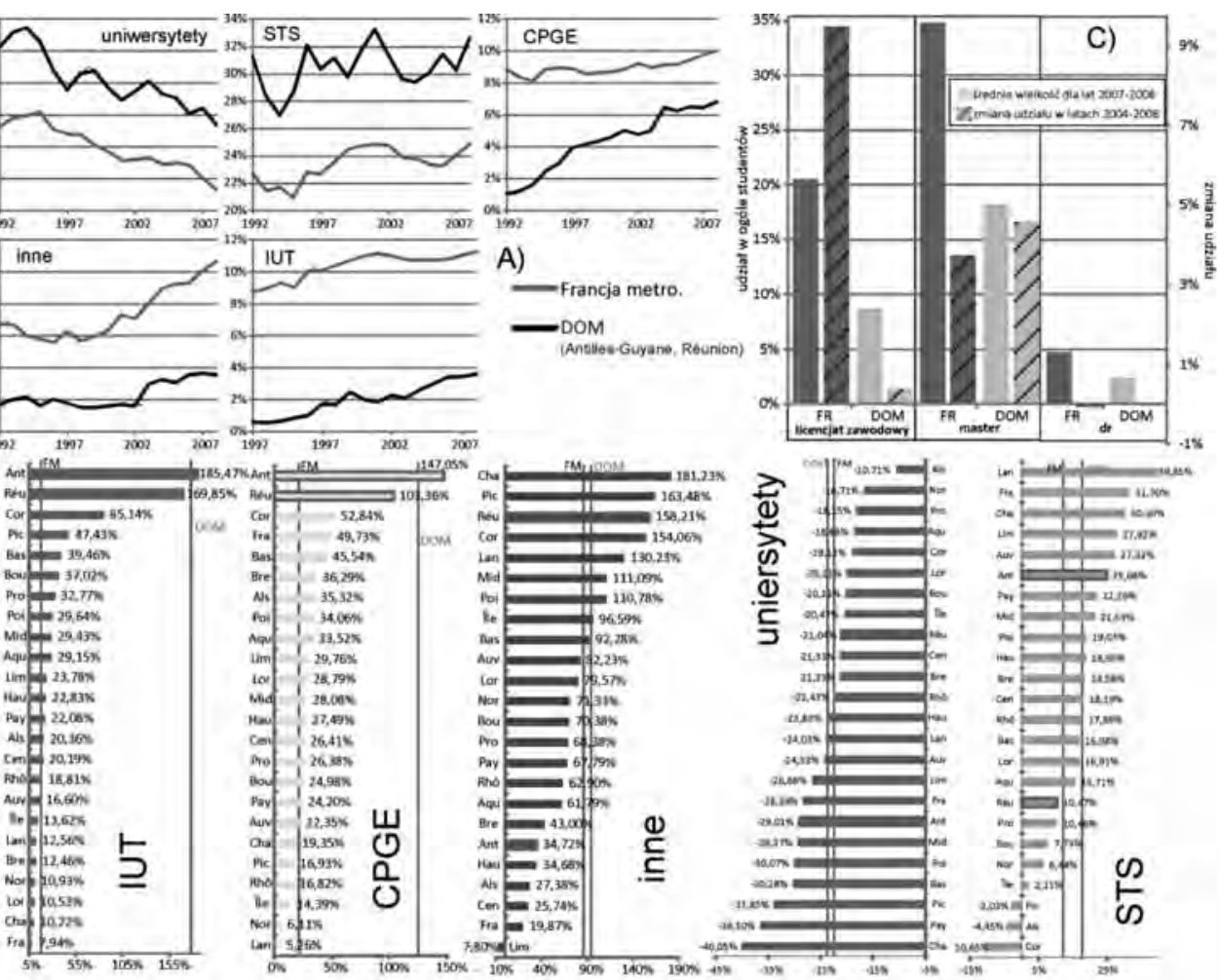

Źródło: opracowanie własne na podstawie danych CÉREQ.

Również w wypadku kształcenia wyższego przeprowadzono regionalną analizę jakości nauki, poddając badaniom udział uzyskanych stopni naukowych w odniesieniu do ogółu studentów danego poziomu edukacyjnego w 2008 roku (ryc. 18). W porównaniu uwzględniono jedynie regiony zamorskie, w których zlokalizowane były uczelnie, a więc Réunion i Gujanę Francuską. Najwyższy odsetek (>30\%) licencjatów zawodowych w stosunku do ogółu liczby studentów tego poziomu nauki odnotowano w regionach Masywu Centralnego oraz w Szampanii. Następnymi w kolejności były północnowschodnie, uprzemysłowione regiony Francji 
oraz regiony Półwyspu Bretońskiego i region Centrum. Również wysokie wartości uzyskano na południu kraju, w Prowansji i na Korsyce. Najniższy udział poza regionami DOM $(<10 \%)$ odnotowano w regionach południowej Francji, a także Normandii oraz Basenu Paryskiego $(<20 \%)$.

Ryc. 18. Odsetek uzyskanych stopni naukowych na uczelniach w odniesieniu do ogółu studentów danego poziomu edukacyjnego* w regionach FM i DOM w 2008 roku

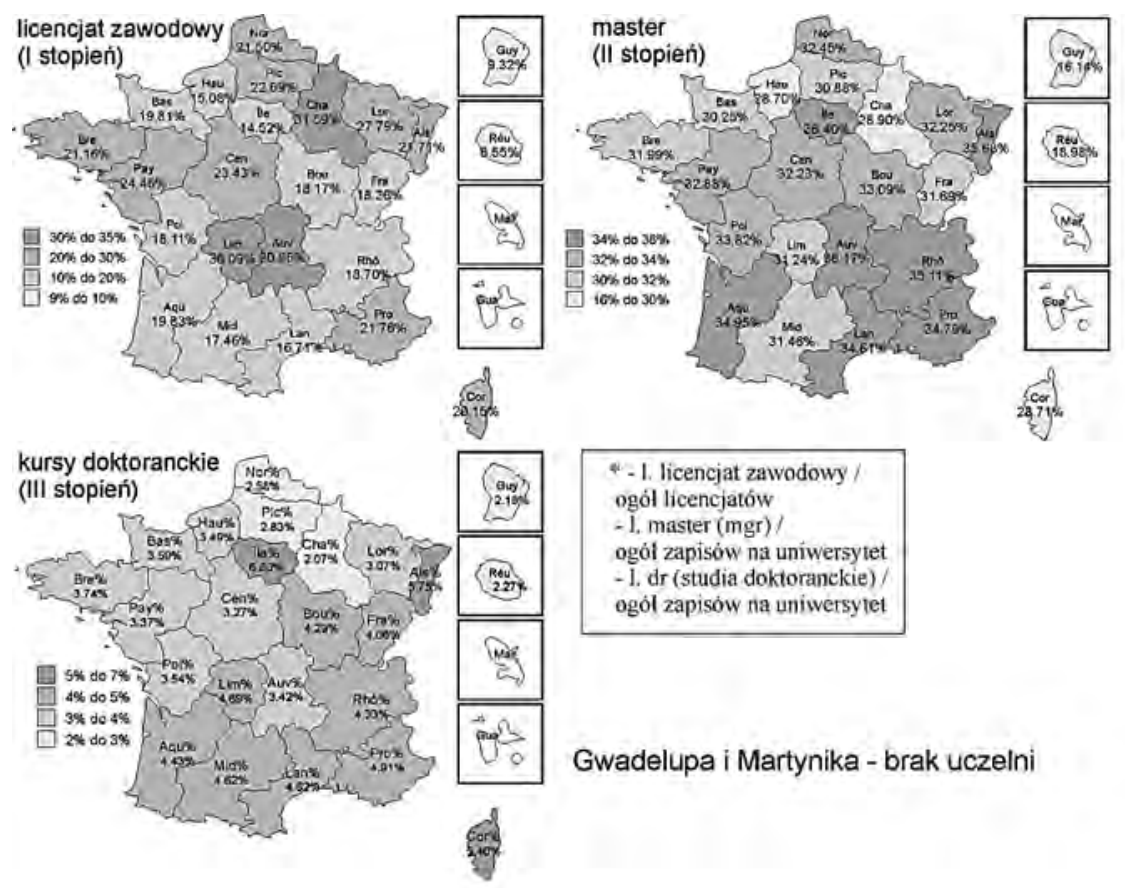

Źródło: opracowanie własne na podstawie danych CÉREQ.

Według liczby uzyskanych dyplomów magistra (maître) w stosunku do ogółu zapisów na studia na pierwszym miejscu uplasował się region Île-de-France (36,4\%). Następnymi w kolejności były regiony związane z oddziaływaniem Lyonu i Marsylii (Owernia, region Rodan-Alpy, Langwedocja i Prowansja) oraz regiony Alzacji i Akwitanii (ok. 35\%). Udział magistrów w jednostkach zamorskich nie przekraczał poziomu $20 \%$. Tytuł doktora nauk uzyskiwało we Francji tylko mniej niż 7\% osób rozpoczynających studia. Największy ich odsetek stwierdzono w regionie Paryża (6,8\%), Alzacji (5,7\%) oraz na Korsyce (5,4\%). W pozostałych regionach położonych na południe od Basenu Paryskiego (z wyjątkiem Owernii) wskaźnik ten kształtował się na poziomie 4-5\%. Najmniej studentów uczestniczyło w kursach doktoranckich w Szampanii $(2,1 \%)$ oraz Gujanie $(2,2 \%)$ i Réunion $(2,3 \%)$. Nasuwa to wniosek, że udział tytułów naukowych w regionach DOM w latach 2007-2008 był średnio o połowę niższy niż w regionach europejskich Francji (ryc. 17C). Tempo zmian udziału poszczególnych stopni naukowych we Francji zamorskiej i metropolitalnej jest bardziej zróżnicowane. W latach 2004-2008 w wypadku udziału licencjatów zawodowych szybszy o prawie 30\% wzrost odnotowano w Europie. W regionach zamorskich niewiele szybszy był wzrost uzyskania tytułów magistra i doktora. W wypadku tego ostatniego stopnia należy zauważyć, że jego udział na kontynencie stał się mniejszy. 
Na koniec analizy poziomu kształcenia w szkolnictwie wyższym prześledzono zróżnicowanie udziału osób studiujących poza regionem zamieszkania w stosunku do liczby studentów w regionie w 2008 roku (ryc. 19). Wskaźnik ten obrazuje wiarygodność przytoczonych powyżej danych, charakteryzujących społeczne zróżnicowanie regionów pod względem kształcenia na poziomie wyższym oraz określa atrakcyjność uczelni i ich dostępność dla absolwentów szkół średnich. Oceniając zatem wielkość średniego udziału studentów emigrujących za nauką poza region swego zamieszkania, można stwierdzić, że jest on największy w przypadku DOM. Spowodowane jest to głównie poprzez duży udział studentów podejmujących naukę poza francuską Gujaną. W latach 1993-2008 udział emigrujących studentów we Francji metropolitalnej nieznacznie wzrósł z 10\% do 15\%, podczas gdy w Réunion utrzymywał się na prawie niezmienionym poziomie 15\%. Największa zmiana udziału nastąpiła w Gujanie Francuskiej, gdzie odnotowano spadek od 2000 roku z 39\% do 20\% (ryc. 19A). W regionach metropolitalnych udział studentów podejmujących studia poza regionem waha się od ok. 3\% w Nord-Pas-de-Calais i Île-de-France do 36\% w Pikardii. Ogólnie niski odsetek studiujących poza regionem odnotowały rozwinięte regiony Alzacji, Lotaryngii i Bretanii (ok. 10\%) (ryc. 19A). We Francji metropolitalnej nastąpił wzrost udziału osób podejmujących naukę poza regionem, wyjątek stanowią dwa regiony: Korsyka i Pikardia, w których nastąpił wyraźny spadek z wysokiego poziomu ponad 40\% do ok. 35\% (ryc. 19B). Tak wysoki udział w Pikardii (podobnie jak w Szampanii oraz Burgundii) może być spowodowany bliskością regionu paryskiego będącego głównym ośrodkiem akademickim kraju, a nawet Europy. W wypadku Korsyki za główny czynnik można przyjąć podejmowanie studiów na kontynencie, natomiast niższy udział w regionach DOM może wynikać z ich oddalenia od innych centrów naukowych oraz związanych z tym kosztów.

Ryc. 19. Udział osób studiujących poza regionem zamieszkania w stosunku do liczby studentów w regionie w latach 1993-2008 (A i B) oraz jego regionalne zróżnicowanie w 2008 r. (C)
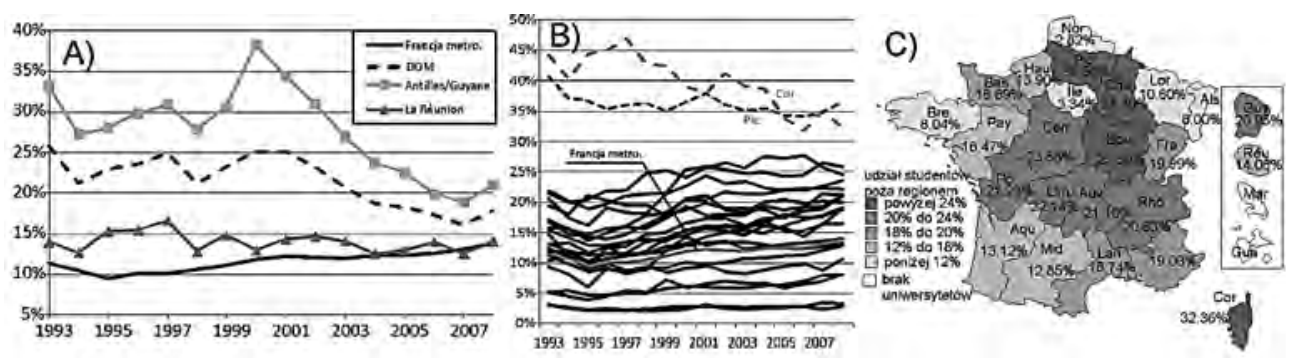

Źródło: opracowanie własne na podstawie danych CÉREQ.

Standaryzowany ${ }^{6}$ poziom kształcenia wyższego w regionach Francji nie wykazuje dużego zróżnicowania (ryc. 20 A). Najwyższe wartości miernika $(>0,15)$ mają regiony z największymi ośrodkami akademickimi, na przykład Lyon i Paryż. Wysokie wartości otrzymały również regiony Pays de la Loire, Midi-Pyrénées i Bretania. Najniższe wartości $(<0)$ odnotowano na

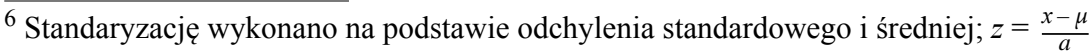


Gwadelupie, Martynice, w Réunion, Gujanie Francuskiej oraz Pikardii, Szampanii, na Korsyce i w Franche-Comté. Świadczy to o utrzymującej się w szkolnictwie wyższym dominacji regionów metropolitalnych, w tym regionów najbardziej rozwiniętych. Należy jednak zwrócić uwagę na powolny wzrost znaczenia regionów peryferyjnych, na przykład Gujany Francuskiej, oraz regionów związanych z innowacyjnością, na przykład w Bretanii i Krainie Loary.

Ryc. 20. Standaryzowany poziom szkolnictwa wyższego (A) i miernik syntetyczny specjalizacji dziedzin wysokich technologii wśród absolwentów poszczególnych rodzajów szkół (B) oraz waga przyjętych cech miernika syntetycznego (C)
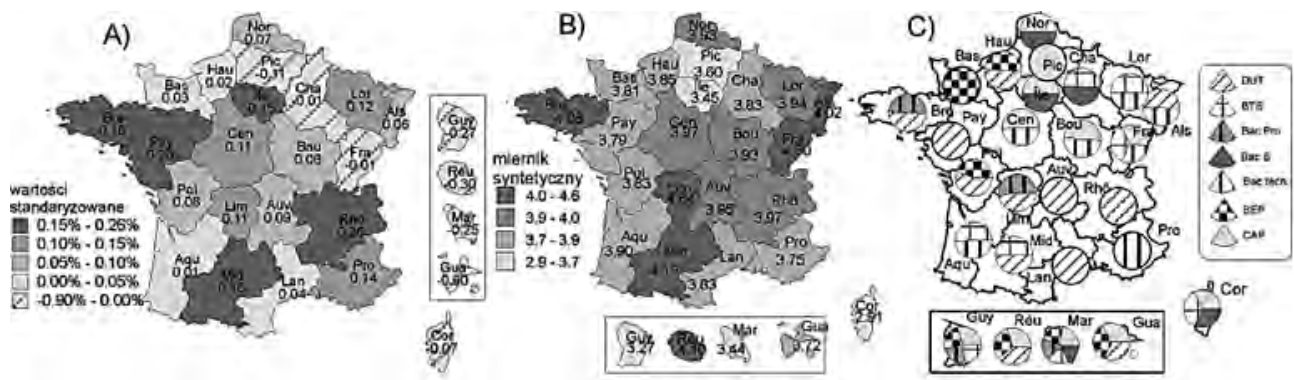

Źródło: opracowanie własne na podstawie danych CÉREQ.

\section{Francuski system edukacyjny w aspekcie gospodarki opartej na wiedzy}

Innym ważnym wskaźnikiem konkurencyjności i przedsiębiorczości w zakresie edukacji w regionach Francji jest wybór kierunku nauki. Przyjmuje się, że innowacyjność gospodarki wpływa obecnie najsilniej na przewagę jej konkurencyjności. Dlatego następną część pracy poświęcono analizie kształcenia w zakresie wysokich technologii na wszystkich poziomach kształcenia. Zaczynając od kształcenia zawodowego (CAP i BEP), większy udział specjalizacji w zakresie wysokich technologii wykazywały regiony zamorskie Francji (ryc. 21A). W wypadku certyfikatu kompetencji zawodowych udział specjalizacji high-tech w DOM w okresie 1997-2008 zmalał z ok. 70\% do 60\%, podczas gdy analogiczny udział we Francji metropolitalnej spadł z 60\% do 45\%. Podobnie w wypadku świadectwa kwalifikacji zawodowych udział specjalizacji high-tech w regionach zamorskich był wyższy i oscylował w granicy ok. 45\%, podczas gdy na kontynencie wynosił ok. 42\%. Na pozostałych stopniach edukacji zawodowej odsetek osób podejmujących specjalizację związaną z wysoką techniką był w obydwu regionach zbliżony do siebie. Jedynie dla matury generalnej z nauk ścisłych oraz matury technicznej ze specjalizacji przemysłu i chemii udział ten był wyraźnie wyższy we Francji metropolitalnej. Świadczyć to może o większym udziale szkolnictwa wyższego w metropolii niż w DOM, co z kolei prowadzi do wzrostu klasy kreatywnej w regionach europejskich Francji (Stryjakiewicz 2008, 2009). Spośród regionów Francji największy (> 4) udział specjalizacji high-tech wśród absolwentów miały Limousin, Alzacja, Franche-Comté, Midi-Pyrénées, Bretania oraz Réunion (ryc. 20B). Najniższe wartości oprócz pozostałych departamentów zamorskich posiadały Korsyka, Pikardia i region paryski oraz zachodnie regiony rolnicze Francji. 
Ryc. 21. Specjalizacja dziedzin wysokich technologii wśród absolwentów poszczególnych rodzajów szkół we Francji i DOM w latach 1997-2008 (A) i udział cudzoziemców wśród wysoko wykwalifikowanej kadry w sektorze high-tech w 2008 roku (B)
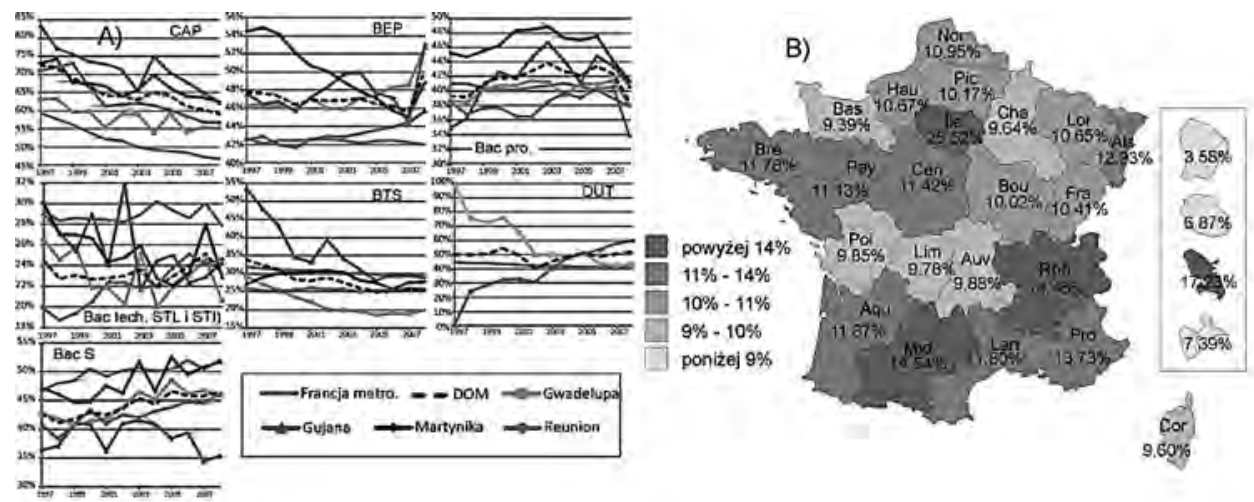

Źródło: opracowanie własne na podstawie danych CÉREQ.

W związku z dużym zróżnicowaniem specjalizacji dokonano analizy wagi przyjętych cech miernika syntetycznego (ryc. 20C). W porównaniu analizowano udział wagi powyżej 15\% wartości miernika. Z otrzymanych danych wynika, że na południu i zachodzie Francji specjalizacja nauki w kierunku zawodów wysokich technologii następowała głównie wśród licencjatów politechniki (DUT) i techników (Bac pro). Na północy i zachodzie kraju większy udział ma specjalizacja wśród absolwentów szkół zawodowych (CAP) i (BEP), techników STI i STL (Bac tech.) oraz maturzystów z kierunku nauki ścisłe (Bac S). W departamentach zamorskich jest ona bardziej zróżnicowana, ale w większości największy udział mają absolwenci szkół zawodowych oraz absolwenci liceów zawodowych, a więc najniższych szczebli nauki. Dodatkowo regiony o wysokim stopniu wykształcenia społeczeństwa są zarazem miejscem rozwoju sektorów wysokiej technologii, które przyciągają wysoko wykwalifikowaną kadrę. Dlatego największy udział cudzoziemców wśród wykwalifikowanej kadry odnotowano w regionie Paryża (ponad 25\%) (ryc. 21B). Również pozostałe regiony o wysokim udziale specjalizacji high-tech wśród uczniów są miejscem napływu wysoko wykwalifikowanej ludności. Wśród departamentów zamorskich największy napływ cudzoziemców odnotowała Martynika. Napływ wykształconej kadry pracowniczej może mieć związek z działalnością Instytutu Badań na rzecz Rozwoju (L'Institut de recherchepour le développement - IRD), który poprzez prowadzone badania naukowe i szkolenia wzmaga społeczno-gospodarczy i kulturalny rozwój Martyniki.

Innym ważnym elementem kształcenia zawodowego i podnoszenia wykwalifikowania absolwentów szkół jest współpraca pomiędzy ośrodkami szkolnictwa a podmiotami gospodarczymi. Udział praktyk zawodowych wśród młodzieży w wieku16-25 lat jest bardzo niski i wynosił w 2007 roku niespełna 3,5\% populacji dla Francji metropolitalnej i ok. 2,0\% dla DOM (ryc. 22). Na obu obszarach udział praktykantów od 1993 roku wzrósł prawie dwukrotnie. Szczególnie wysoki wzrost (do poziomu 5\%) nastąpił na Martynice, podczas gdy w Gujanie Francuskiej po niewielkim wzroście spadł do poziomu z 1993 roku, czyli 0,3\%. Spośród innych regionów o wysokim udziale podpisanych kontraktów praktyk zawodowych wymienić należy: Centrum, Burgundię i Poitou-Charentes. Najmniejszy udział, poza Gwadelupą, Gujaną Francuską i Réunion, miał region paryski, co może być spowodowane dużą populacją młodzieży. 
Ryc. 22. Udział podpisanych kontraktów praktyk zawodowych zawartych przez młodzież w wieku 16-25 lat w stosunku do ogółu populacji w tym przedziale wiekowym we Francji i DOM w latach 1993-2007 oraz zróżnicowanie regionalne i jego zmiana $(1993=100 \%)$
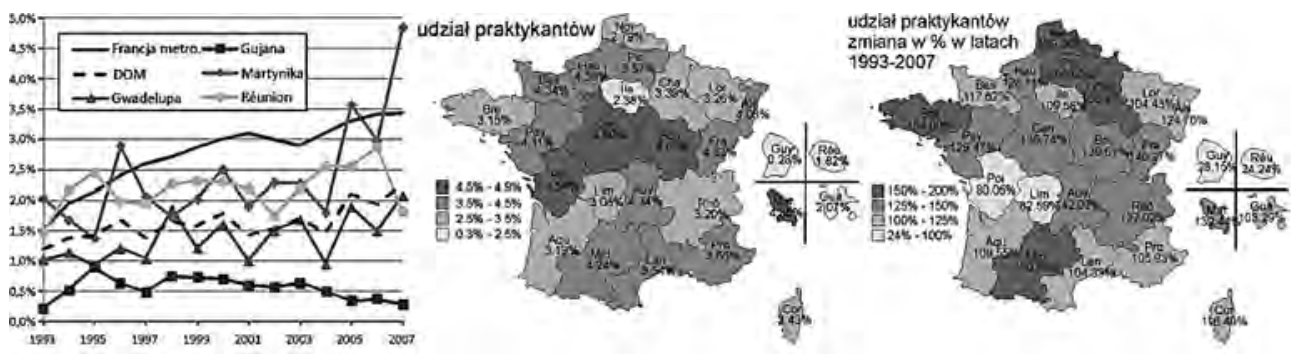

Źródło: opracowanie własne na podstawie danych CÉREQ.

Porównując tempo wzrostu w stosunku do roku 1993, można zauważyć, że w prawie wszystkich regionach Francji nastąpił wzrost liczby praktykantów o ok. 100\%. Wyjątek stanowiły Gujana Francuska i Réunion, gdzie wzrost nie przekroczył 30\%, oraz Poitou-Charentes i Limousin ze wzrostem ok. 80\%. Największy wzrost nastąpił w Pikardii (199\%), regionach północnych (Nord-Pas-de-Calais, Champagne-Ardenne i Pikardia), Midi-Pyrénées i Bretanii (ok. 150\%). Wysoki wzrost nastąpił zarówno w regionach wysoko rozwiniętych, jak i ośrodkach o niskim poziomie rozwoju i szkolnictwa. Istnieje też możliwość, że część uczniów pobierających naukę przykładowo w Paryżu, podejmowała praktyki w regionie swojego zamieszkania.

\section{Mierniki syntetyczne szkolnictwa}

W celu porównania efektów kształcenia z regionalnym poziomem jakości kapitału ludzkiego związanego z innowacyjnością gospodarki, przeprowadzono syntezę poziomu szkolnictwa w regionach Francji na każdym etapie edukacyjnym. Dokonano zatem transformacji wszystkich analizowanych wskaźników w celu uzyskania porównywalnego materiału badawczego i zastosowano następujące metody badawcze: analizę wartości standaryzowanych względem wartości odchylenia standardowego, analizę skupień z zastosowaniem odległości euklidesowych oraz wskaźnik syntetyczny metody Z. Zioło (1972, 1985). Porównując otrzymane wyniki we wszystkich analizowanych przypadkach, widać, że departamenty zamorskie posiadają najniższe wartości, świadczące o utrzymującej się przepaści poziomu kształcenia pomiędzy metropolią a DOM (ryc. 23). Najgorsze wyniki odnotowano w Gujanie Francuskiej. Spośród regionów zamorskich najlepsze wskaźniki odnotowano w Réunion i na Martynice. Dla regionów europejskich wyniki wykazują mniejsze zróżnicowanie. Najwyższy poziom kształcenia odnotowano w regionach: Rhône-Alpes, Midi-Pyrénées i Bretanii, a więc na obszarach najbardziej kreatywnych i rozwijających się. Może zaskakiwać stosunkowo niska pozycja regionu paryskiego, jednakże, jak wykazano powyżej, 25\% kadry wysoko wykwalifikowanej stanowią tam cudzoziemcy, nieuczestniczący w procesie kształcenia. Ponadto ośrodek paryski stanowi magnes przyciągający zarówno wykwalifikowanych, jak i niewykwalifikowanych pracowników i ich rodziny, co może wpływać niekorzystnie na uwzględnione w analizie wskaźniki. Najgorsze wyniki na kontynencie uzyskał region Pikardii i Korsyka, którą należy w myśl przeprowadzonych w ostatnich latach reform administracyjnych oraz odmienności kulturowo-społecznej traktować bardziej jako departament zamorski niż region Francji metropolitalnej. Natomiast w wypadku Pikardii, jak i innych sąsiednich regionów, wpływać na taki stan rzeczy może bliskość Paryża jako ośrodka odpowiedzialnego za proces wymywania kapitału ludzkiego. 
Ryc. 23. Wartości standaryzowane poziomu szkolnictwa dla regionów Francji oraz analiza skupień regionów Francji wg poziomu szkolnictwa i wskaźnik syntetyczny poziomu szkolnictwa we Francji w 2008 roku

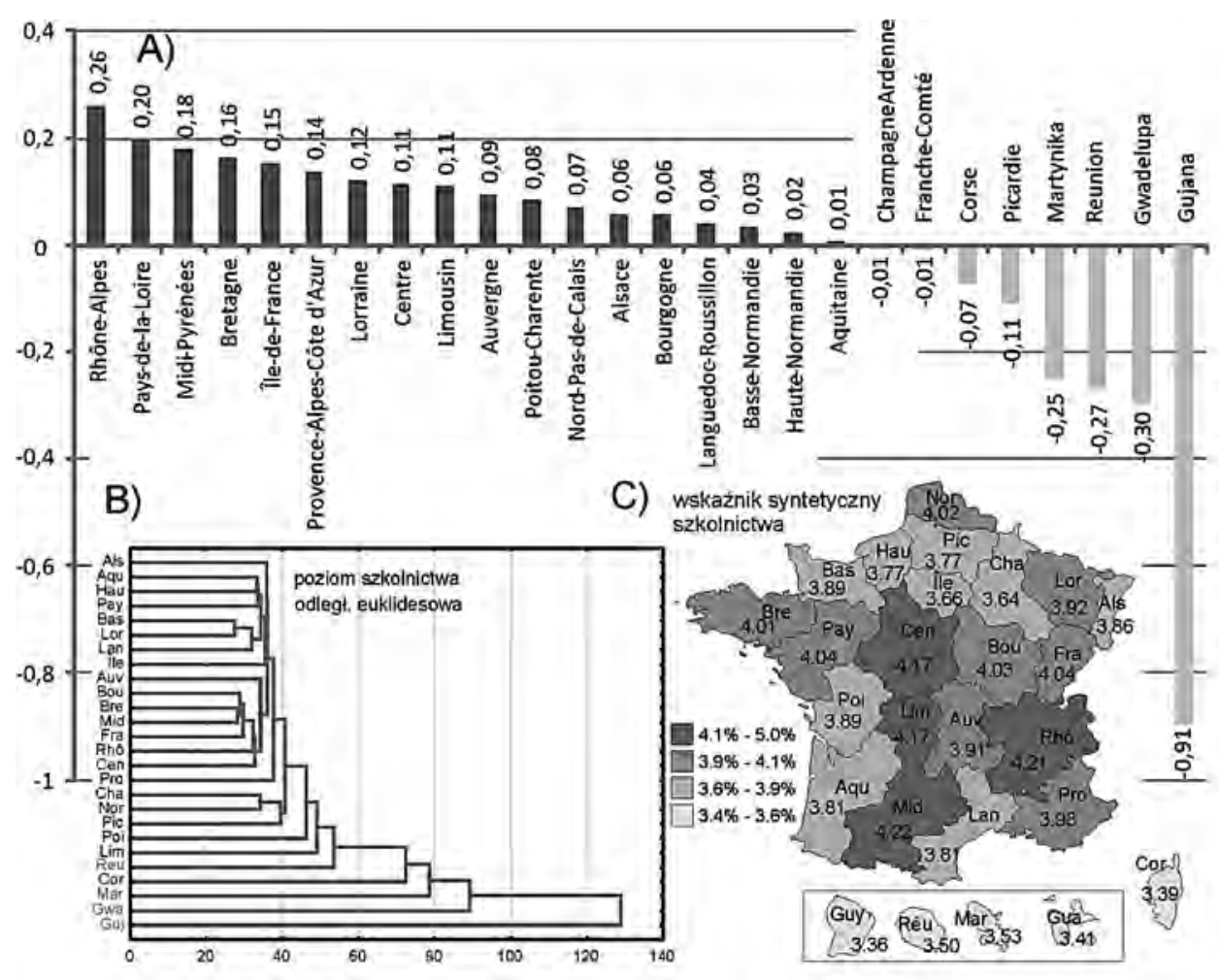

Źródło: opracowanie własne na podstawie danych CÉREQ.

Na wysoką pozycję regionów peryferyjnych wpłynęły głównie wagi związane z kształceniem zawodowym, praktykami i specjalizacją kształcenia na niższych poziomach edukacyjnych, natomiast $\mathrm{w}$ regionach rozwiniętych większe znaczenie miało kształcenie wyższe oraz powszechność szkolnictwa i otrzymywane wyniki w nauce. Potwierdza się zatem teza o większym znaczeniu kształcenia na poziomie wyższym w odniesieniu do rozwoju gospodarczego regionów.

Rozpatrując z kolei zmianę w czasie wszystkich analizowanych wskaźników, można dostrzec ujemną korelację pomiędzy regionalnymi wartościami danych wskaźników kształcenia a wartościami ich zmiany. W regionach o najniższych wartościach danych wskaźników kształcenia następuje najszybszy ich wzrost, co z czasem może doprowadzić do ich regionalnego wyrównania.

\section{Regionalne zróżnicowanie kapitału ludzkiego w gospodarce Francji}

$\mathrm{Na}$ koniec przeprowadzono próbę porównania związku pomiędzy regionalnym poziomem edukacji a kapitałem ludzkim, powiązanym z gospodarką opartą na wiedzy i innowacyjnością. W tym celu dokonano standaryzacji następujących cech: udział kadry $B+R$ oraz jej zmiana w latach 1999-2008, liczba instytucji B+R, pracownicy umysłowi wśród zatrudnionych w wieku 
15-64 lata w 2008 roku, pracownicy zakładów high-tech oraz udział tych zakładów ${ }^{7}$, udział klasy kreatywnej (core) w 2006 roku, liczba pracowników publikujących z uznanych jednostek naukowych w latach 2004-2007, instytucje badawcze i rozwoju wysokiej techniki oraz miejsca pracy w tych instytucjach. Zauważyć należy, że wszystkie analizowane cechy były ze sobą silnie powiązane.

Dokonując standaryzacji powyższych cech metodą wskaźnika syntetycznego i analizą skupień, otrzymano obraz regionalnego zróżnicowania kapitału ludzkiego w gospodarce Francji (ryc. 24). Na jego podstawie można stwierdzić, że departamenty zamorskie charakteryzują się najniższym poziomem kapitału ludzkiego gospodarki wśród regionów Francji. DOM otrzymały najniższe $(<2)$ wartości wskaźnika (Gujana Francuska miała najniższą wartość - 1,12), podobnie jak Korsyka i Limousin. Najwyższą wartość, deklasującą pozostałe regiony, miał region Île-de-France $(19,81)$. Świadczy to o dalszej dominacji Paryża w przestrzenni nie tylko gospodarczej, lecz i innowacyjnej Francji. Następnymi w kolejności były regiony Rodan-Alpy $(9,4)$ oraz Prowansja $(6,0)$. Również wysoki $(>4)$ wskaźnik miały regiony Midi-Pyrénées, Kraina Loary, Akwitania i Alzacja.

Ryc. 24. Regionalne zróżnicowanie poziomu kapitału ludzkiego w gospodarce regionów Francji w 2008 roku na podstawie wskaźnika syntetycznego kapitału ludzkiego i analizy skupień

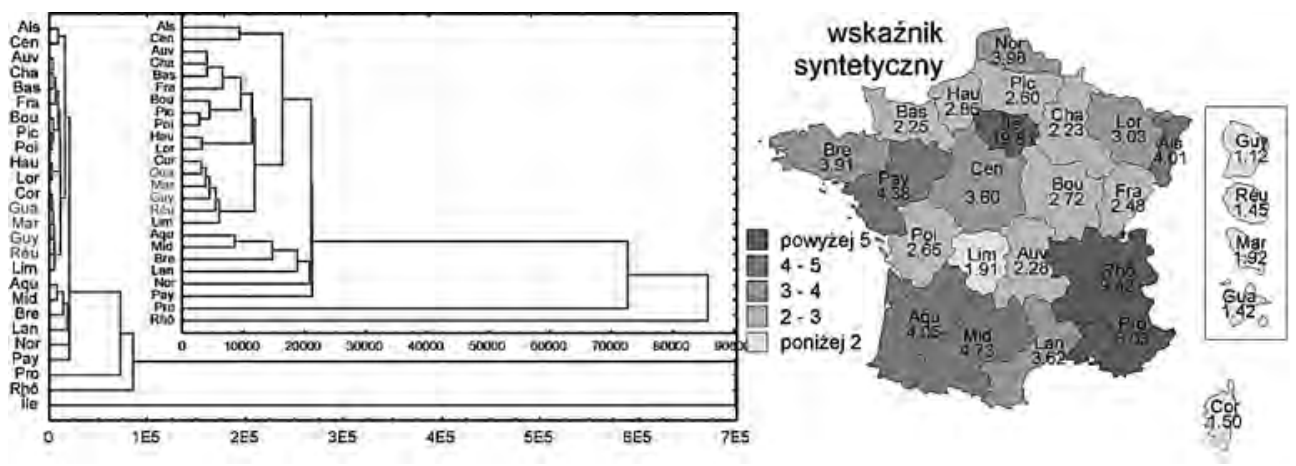

Źródło: opracowanie własne na podstawie danych INSEE.

Porównując zatem wskaźniki syntetyczne edukacji i kapitału ludzkiego w regionach Francji, można zauważyć zgodność w rozmieszczeniu wartości obu indeksów. Regiony o wysokim poziomie kształcenia posiadają również wysoko wykwalifikowaną kadrę roboczą. Wyjątek stanowić może region paryski i Bretania, jednakże w obu przypadkach mogły na to wpłynąć inne czynniki, o czym była już mowa między innymi na wstępie niniejszego artykułu.

W celu dokładniejszej analizy zaistniałych zależności dokonano zestawienia 80 zmiennych, obrazujących szkolnictwo i sferę innowacyjności regionów Francji, ze statystycznych tabel zbiorczych INSEE dla 2006 roku. Spośród wszystkich cech wybrano te najsilniej skorelowane, mające największe znaczenia dla rozwoju innowacyjności (tab. 1). Porównanie średnich wartości współczynnika korelacji pozwala domniemać, że poziom wysoko wykwalifikowanej kadry ma silny związek z udziałem absolwentów szkół wyższych, głównie kierunkowych, udziałem absolwentów szkół technicznych i ekonomicznych w ogóle szkół ponadgimnazjalnych,

\footnotetext{
${ }^{7} \mathrm{~W}$ analizie uwzględniono udział zakładów high-tech ze względu na fakt, że charakteryzują się one małym zatrudnieniem, które może nie oddawać ich znaczenia w gospodarce regionu (Lundin, Sjöholm, Qian 2006).
} 
powszechnością praktyk zawodowych oraz dostępnością szkolnictwa na poziomie gimnazjum. Powyższe wskaźniki są z kolei silnie skorelowane z liczbą instytucji badawczych w regionie i miejscami pracy w tych instytucjach oraz ogólnie z kadrą intelektualną regionów.

Tab. 1. Związki pomiędzy edukacją a kapitałem ludzkim w ujęciu innowacyjności w gospodarce regionalnej Francji w 2006 roku

\begin{tabular}{|c|c|c|c|c|c|c|c|}
\hline & 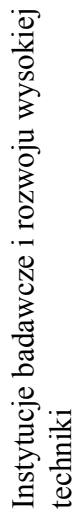 & 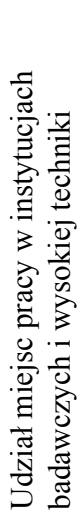 & 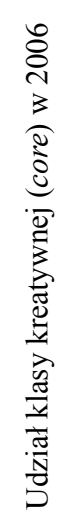 & 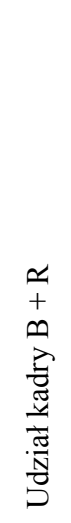 & 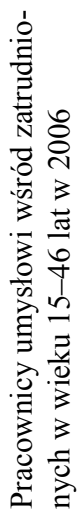 & 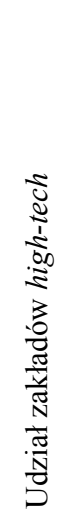 & 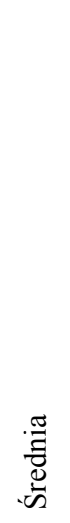 \\
\hline Absolwenci szkoły techn. w ogóle szkół & 0,97 & 0,96 & 0,95 & 0,94 & 0,94 & 0,97 & 0,96 \\
\hline $\begin{array}{r}\text { Absolwenci wyższych szkół } \\
\text { nieuniwersyteckich (\%) }\end{array}$ & 0,99 & 0,99 & 0,96 & 0,95 & 0,92 & 0,91 & 0,95 \\
\hline Absolwenci innych szkół wyższych (\%) & 0,98 & 0,97 & 0,95 & 0,94 & 0,93 & 0,93 & 0,95 \\
\hline $\begin{array}{r}\text { Liczba praktyk zawodowych w stosunku } \\
\text { do ogólnej liczby absolwentów - poziom } \\
\text { szkolnictwa III }\end{array}$ & 0,96 & 0,96 & 0,95 & 0,93 & 0,93 & 0,95 & 0,95 \\
\hline $\begin{array}{r}\text { Udział szkół ekonomicznych w ogóle szkół } \\
\text { ponadgimnazjalnych }\end{array}$ & 0,97 & 0,98 & 0,96 & 0,95 & 0,93 & 0,90 & 0,95 \\
\hline $\begin{array}{l}\text { Liczba praktyk zawodowych w stosunku } \\
\text { do ogólnej liczby absolwentów - poziom I i III }\end{array}$ & 0,98 & 0,99 & 0,94 & 0,93 & 0,91 & 0,87 & 0,94 \\
\hline $\begin{array}{r}\text { Liczba college'ów w stosunku } \\
\text { do liczby młodzieży }\end{array}$ & 0,92 & 0,91 & 0,92 & 0,89 & 0,92 & 0,95 & 0,92 \\
\hline $\begin{array}{l}\text { Uczniowie odbywający praktyki zawodowe } \\
\text { w stosunku do ogólnej liczby absolwentów }\end{array}$ & 0,91 & 0,90 & 0,92 & 0,89 & 0,92 & 0,95 & 0,92 \\
\hline Średnia & 0,96 & 0,96 & 0,94 & 0,93 & 0,93 & 0,93 & \\
\hline
\end{tabular}

Źródło: opracowanie własne na podstawie danych INSEE.

Na podstawie powyższych dociekań można potwierdzić istnienie różnic w poziomie kształcenia pomiędzy regionami Francji metropolitalnej i Francji zamorskiej. Pomimo że departamenty zamorskie, posiadające jednocześnie status regionów, otrzymują takie same środki finansowe jak metropolitalne jednostki administracyjne i, stanowiąc integralną część Republiki, korzystają ze wspólnotowych grantów przeznaczonych na rozwój działalności edukacyjnej, naukowej i gospodarczej, analizowane wskaźniki edukacyjne były w nich w większości o wiele niższe niż na kontynencie. Powodów tego stanu rzeczy jest wiele, przy czym należy zwrócić 
uwagę na egalitarność francuskiego sytemu edukacji. Proces kształcenia, począwszy od szkolnictwa przedszkolnego po szkolnictwo wyższe, odbywa się wedle tych samych reguł we wszystkich regionach Francji, nie uwzględniając ich specyfiki. Ponadto, system szkolnictwa prywatnego, który jest bardziej elastyczny, ze względu na uwarunkowania materialne pozostaje znacznie słabiej rozwinięty w DOM niż we Francji metropolitalnej. Problemy edukacyjne departamentów zamorskich w dużej mierze powodowane są ich kolonialną przeszłością, w tym uprzywilejowaną pozycją języka kreolskiego w jego różnych odmianach. Również znaczne zróżnicowanie kulturowo-etniczne, wzmagane dodatkowo przez niedostosowanie materiałów edukacyjnych, utrudnia proces kształcenia już na poziomie elementarnym. Jedynymi publicznym ośrodkami kształcenia akademickiego pozostają Uniwersytet Antyli i Gujany Francuskiej oraz Uniwersytet Réunion, podczas gdy wszystkie najbardziej prestiżowe grandes écoles (a zatem politechniki, uczelnie techniczne i inne) zlokalizowane są w metropolii, co działa na niekorzyść studentów zamorskich. Dlatego też regiony europejskie Francji dominują nad regionami zamorskimi zarówno pod względem szkolnictwa podstawowego, jak i średniego oraz wyższego. Szczególnie istotne dla dalszego rozwoju gospodarczego DOM są dysproporcje w efektach kształcenia oraz struktura szkolnictwa nastawiona głównie na kształcenie zawodowe. W związku z powyższym tendencje do wyrównania dysproporcji pomiędzy metropolią a regionami zamorskimi są widoczne jedynie na niższych szczeblach kształcenia. Departamenty zamorskie Francji charakteryzuje zatem rozwój szkolnictwa zawodowego na poziomie ponadgimnazjalnym, średnim oraz wyższym na poziomie licencjata.

Dokonując regionalnego porównania poziomu edukacji we Francji można zaobserwować, że najgorsza sytuacja panuje w Gujanie Francuskiej i na Gwadelupie, w pozostałych DOM oraz na Korsyce, w Pikardii i Limousin. Najwyższe wyniki kształcenia mają natomiast regiony: Rodan-Alpy, Bretania, Środkowe Pireneje, Kraina Loary oraz Île-de-France. Regionalne zróżnicowanie poziomu edukacji jest zgodne z regionalnym rozmieszczeniem kadry pracowniczej w aspekcie gospodarki opartej na wiedzy. Istnieje zatem zależność pomiędzy poziomem kształcenia a kapitałem ludzkim. Za czynniki najsilniej powiązane z poziomem wykształcenia pracowników i innowacyjnością gospodarki przyjąć należy powszechność szkolnictwa i jego specjalizacje, wykształcenie wyższe techniczne wśród absolwentów szkół oraz współpracę pomiędzy instytucjami naukowymi a przedsiębiorstwami, odbywającą się poprzez praktyki zawodowe uczniów. Należy zatem stwierdzić, że polityka regionalna na obszarze DOM wymaga jeszcze dużych nakładów środków w celu pobudzenia przedsiębiorczości regionów zamorskich, poprzez stymulowanie rozwoju kapitału ludzkiego powiązanego z procesem kształcenia ludności.

\section{Literatura}

1. Atlas régional: les effectifs d'étudiants [lata 2000-2011], Ministère de l'Enseignement supérieur et de la Recherche, Paris, http://www.enseignementsup-recherche.gouv.fr.

2. Bednarz N., 2007, Czy uczenie się przez cate życie jest postawa przedsiębiorcza [w:] Rola przedsiębiorczości w aktywizacji gospodarczej, Z. Zioło, T. Rachwał (red.), „Przedsiębiorczość - Edukacja”, nr 3, wydawnictwo Nowa Era, Zakład Przedsiębiorczości i Gospodarki Przestrzennej Akademii Pedagogicznej im. Komisji Edukacji Narodowej w Krakowie, Warszawa - Kraków, s. 151-155.

3. Borowiec M., 2007, Rola szkolnictwa wyższego w podnoszeniu jakości kapitalu ludzkiego [w:] Rola przedsiębiorczości w aktywizacji gospodarczej, Z. Zioło, T. Rachwał (red.), „Przedsiębiorczość - 
- Edukacja”, nr 3, wydawnictwo Nowa Era, Zakład Przedsiębiorczości i Gospodarki Przestrzennej Akademii Pedagogicznej im. Komisji Edukacji Narodowej w Krakowie, Warszawa - Kraków, s. $142-150$.

4. Borowiec M., 2008a, Rola kapitału ludzkiego w procesie podnoszenia konkurencyjności układów przestrzennych [w:] Przeksztatcenia regionalnych struktur funkcjonalno-przestrzennych, Europa bez granic - nowe wyzwania, D. Ilnicki, K. Janc (red.), „Rozprawy Naukowe Instytutu Geografii i Rozwoju Regionalnego Uniwersytetu Wrocławskiego 3", Wrocław.

5. Borowiec M., 2008b, Rola szkolnictwa wyższego w procesie ksztaltowania gospodarki opartej na wiedzy [w:] Rola przedsiębiorczości w gospodarce opartej na wiedzy, Z. Zioło, T. Rachwał (red.), „Przedsiębiorczość - Edukacja”, nr 4, wydawnictwo Nowa Era, Zakład Przedsiębiorczości i Gospodarki Przestrzennej Instytutu Geografii Uniwersytetu Pedagogicznego im. Komisji Edukacji Narodowej w Krakowie, Warszawa - Kraków, s. 25-34.

6. Borowiec M., 2011, Rola edukacji w procesach globalizacji [w:] Rola przedsiębiorczości w gospodarce opartej na wiedzy, Z. Zioło, T. Rachwał (red.), „Przedsiębiorczość - Edukacja”, nr 4, wydawnictwo Nowa Era, Zakład Przedsiębiorczości i Gospodarki Przestrzennej Instytutu Geografii Uniwersytetu Pedagogicznego im. Komisji Edukacji Narodowej w Krakowie, Warszawa - Kraków, s. 296-307.

7. Borowiec M., Dorocki S., 2010, The process of transformation of academic centres as a factor upgrading the quality of human capital in the regions of France, "Bulletin of Geography (socio-economic series)", Torun (w druku).

8. Borowiec M., Dorocki S., Jenner B., 2009, Wpływ zasobów kapitału ludzkiego na kształtowanie społeczeństwa informacyjnego i innowacyjności struktur przemysłowych [w:] Funkcje przemystu w ksztaltowaniu społeczeństwa informacyjnego, Z. Zioło, T. Rachwał (red.), „Prace Komisji Geografii Przemysłu PTG”, nr 13, Komisja Geografii Przemysłu PTG, Zakład Przedsiębiorczości i Gospodarki Przestrzennej, Instytut Geografii, Uniwersytet Pedagogiczny w Krakowie Wydawnictwo Naukowe UP w Krakowie, Warszawa - Kraków, s. 95-109.

9. Brzegowy P., Dorocki. S., 2010, Les départements français d'Amérique - artefakty kolonialnej przeszłości Francji, „Kultura i Polityka 8”, Kraków, s. 179-199.

10. Chojnicki Z., Czyż T., 2003, Poland on the Road to a Knowledge-Based Economy: A Regional Approach, In Recent Advances in Urban and Regional Studies, Polish Academy of Sciences, Committee for Space Economy and Regional Planning.

11. Chojnicki Z., Czyż T., 2006, Aspekty regionalne gospodarki opartej na wiedzy w Polsce, Bogucki Wydawnictwo Naukowe, Poznań.

12. Chojnicki Z., Czyż T., 2007, Rola kapitału ludzkiego w kształtowaniu gospodarki opartej na wiedzy w Polsce, „Przegląd Geograficzny 79”, 3-4, s. 423-428

13. Chojnicki Z., Czyż T., 2008, Gospodarka oparta na wiedzy w regionach metropolitalnych $i$ aglomeracjach miejskich $w$ Polsce [w:] Rola polskich aglomeracji wobec wyzwań strategii lizbońskiej, T. Marszał (red.), Studia KPZK PAN, Warszawa, s. 74-75.

14. Dorocki S., 2008, Gospodarka oparta na wiedzy w założeniach strategii lizbońskiej na przykładzie Francji [w:] Rola przedsiębiorczości w gospodarce opartej na wiedzy, Z. Zioło, T. Rachwał (red.), „Przedsiębiorczość - Edukacja”, nr 4, wydawnictwo Nowa Era, Zakład Przedsiębiorczości i Gospodarki Przestrzennej Instytutu Geografii Uniwersytetu Pedagogicznego im. Komisji Edukacji Narodowej w Krakowie, Warszawa - Kraków, s. 176-184.

15. Goldberg I., 2004, Poland and the Knowledge Economy. Enhancing Poland's Competitiveness in European Union, The World Bank, Washington D.C., "Rewasz" Publishing House, Pruszków, Poland.

16. Grodzicki J., 2000, Edukacja czynnikiem rozwoju gospodarczego, Wydawnictwo Adam Marszałek, Torun.

17. Komorowski J.W., 2008, Zróżnicowanie przestrzenne i dynamika akademickiego potencjatu ksztatcenia dla gospodarki innowacyjnej w Polsce [w:] Mechanizmy i uwarunkowania budowania konkurencyjności miast. Miasta w okresie przemian, J. Słodczyk, E. Szafranek (red.), Wydawnictwo Uniwersytetu Opolskiego, Opole, s. 113-129.

18. Kuźnicki L., 2004, Polska w obliczu wyzwań przyszłości. W świetle studiów Komitetu Prognoz „Polska 2000 Plus" Polskiej Akademii Nauk, Elipsa, Warszawa. 
19. Lundin N., Sjöholm F., Qian J., 2006, The role of small firms in china's technology development, Working Paper, European Institute of Japanese Studies 227, Stockholm, Sweden.

20. Łukaszewicz G., 2009, Kapitał ludzki organizacji. Pomiar i sprawozdawczość, Wydawnictwo Naukowe PWN, Warszawa.

21. Pietrzyk I., 1992, Sterowanie rozwojem regionalnym we Francji, Studia KPZK PAN, t. XCIX, Warszawa.

22 Runiewicz-Wardyn M. (red.), 2008, Knowledge-Based Economy as a Factor of Competitiveness and Economic Growth, Academic and Professional Press, Leon Koźmiński Academy of Entrepreneurship and Management, Warszawa.

23. Simonin J., Wolff E., 1992, École et famille à la Réunion: un lien problématique, in: Revue française de pédagogie, Volume 100, s. 36-40.

24. Sowiński T., 2008, Zasoby kapitału ludzkiego w miastach a rozwój gospodarczy regionu [w:] Mechanizmy i uwarunkowania budowania konkurencyjności miast. Miasta w okresie przemian, J. Słodczyk, E. Szafranek (red.), Wydawnictwo Uniwersytetu Opolskiego, Opole, s. 79-87.

25. Stryjakiewicz T., 2008, Sektor kreatywny jako czynnik ksztattujący nowa jakość przestrzeni europejskiej [w:] Przeksztatcanie regionalnych funkcjonalno-przestrzennych, Europa bez granic - nowe wyzwania, D. Ilnicki, K. Janc (red.), „Rozprawy Naukowe Instytutu Geografii i Rozwoju Regionalnego Uniwersytetu Wrocławskiego 3”, Instytut Geografii i Rozwoju Regionalnego Uniwersytetu Wrocławskiego, Wrocław, s. 11-18.

26. Stryjakiewicz T., 2009, Lokalizacja firm i zachowania przestrzenne pracowników sektora informatycznego (na przykładzie poznańskiego obszaru metropolitalnego) [w:] Funkcje przemystu w ksztattowaniu społeczeństwa informacyjnego, Z. Zioło i T. Rachwał (red.), „Prace Komisji Geografii Przemysłu PTG”, nr 13, Komisja Geografii Przemysłu PTG i Instytut Geografii Uniwersytetu Pedagogicznego w Krakowie, Warszawa-Kraków, s. 21-33.

27. Świtała J., 2007, Wpływ kapitału ludzkiego na rozwój regionalny w Polsce w kontekście gospodarki opartej na wiedzy [w:] Innowacyjność w budowaniu gospodarki wiedzy w Polsce, S. Pangsy-Kania, E. Okoń-Horodyńska (red.), Instytut Wiedzy i Innowacji, Warszawa.

28. Zioło Z., 1972, Próba konstrukcji miernika syntetycznego w zastosowaniu do badań przemysłu, Komisja Nauk Geograficznych, Sprawozdania z posiedzeń Komisji Naukowych PAN Oddział w Krakowie, t. XV/1, Kraków, s. 191-194.

29. Zioło Z., 1985, Zastosowanie miernika syntetycznego w badaniach układów przestrzennych w geografii przemystu. Seminarium sekcji geografii Przemystu PTG, WSP, Kraków, s. 1-11.

30. Zioło Z., 2007, Rola przedsiębiorczości w aktywizacji gospodarczej-zarys modelu [w:] Rola przedsiębiorczości w aktywizacji gospodarczej, Z. Zioło, T. Rachwał (red.), „Przedsiębiorczość - Edukacja”, nr 3, wydawnictwo Nowa Era, Zakład Przedsiębiorczości i Gospodarki Przestrzennej Akademii Pedagogicznej im. Komisji Edukacji Narodowej w Krakowie, Warszawa - Kraków, s. 10-17.

31. Zioło Z., 2009, Rola przedsiębiorczości w ksztaltowaniu społeczeństwa informacyjnego [w:] Rola przedsiębiorczości w ksztaltowaniu społeczeństwa informacyjnego, Z. Zioło, T. Rachwał (red.), „Przedsiębiorczość - Edukacja”, nr 5, wydawnictwo Nowa Era, Zakład Przedsiębiorczości i Gospodarki Przestrzennej Instytutu Geografii Uniwersytetu Pedagogicznego im. Komisji Edukacji Narodowej w Krakowie, Warszawa - Kraków, s. 10-18.

\section{Źródła}

1. Szkolnictwo (CEREQ):

http://www.cereq.fr/gsenew/base\%20indicateurs/... (różne pliki)

2. Kapitał ludzki (tablice zbiorcze INSEE):

www.statistiques-locales.insee.fr/Fiches\%5 CTC\%5Fiches-TC-TC... (różne pliki)

3. Kształcenie wyższe:

http://media.enseignementsup-recherche.gouv.fr/file/Atlas_2009-2010/45/5/tableaux_regionaux_ Atlas_09-10_170455.xls

http://media.enseignementsup-recherche.gouv.fr/file/2000/75/6/5025_31756.pdf 
4. Wyniki CE1 i CE2:

http://www.education.gouv.fr/pid20946/evaluation-des-acquis-filtre-academie.html

5. Zatrudnienie:

insee.fr/fr/ppp/bases-de-donnees/.../employ_1998-2007.xls

http://epp.eurostat.ec.europa.eu/portal/page/portal/region_cities/regional_statistics/data/database

\section{Regional diversity of education in France with respect to entrepreneurial development of overseas departments}

Regional policy concerning territorial development of the country, while reducing disparities in regional development in France has existed for nearly half a century. It beginnings reach 1963 when DATAR - an institution coordinating regional development of France was established (Délégation à l'aménagement du territoire et à l'action régionale). Additionally, European institutions have started to work, particularly from the 90 s of the 20th century, on implementing the cohesion policy at the regional levels.

Regional policy covers the entire territory of the Republic of France, including its former colonial territories of DOM: French overseas departments (départements d'outre-mer). DOM includes: Guadeloupe, French Guyana, Martinique and Reunion. These regions despite undertaken actions aiming at their economic development are still struggling with various issues. The most significant are the natural and historical constrains, economic dependence on France and the EU financial assistance, supremacy of agriculture, tourism and housing, unemployment and poverty of society and finally the social problems associated with multiculturalism. Actions undertaken by national and regional authorities are predominantly focused on developing the infrastructure and stimulating business development through knowledge transfer and investments in human capital. Recognizing the fact that investing in human is the most essential factor in the growth and socio-economic progress, the aim of this paper is to analyze regional differences in educational level and structure of the population of overseas and mainland France as well as its changes since the 90 s basing on statistical data. The second part presents the regional comparison of the selected indicators of human capital development in the French economy with selected data showing the quantitative changes in the education of France. 